\title{
Genes in concert
}

Citation for published version (APA):

de Kok, T. M. C. M. (2016). Genes in concert: a toxicogenomics hymn towards disease prevention. Maastricht University. https://doi.org/10.26481/spe.20160422tk

\section{Document status and date:}

Published: 22/04/2016

DOI:

10.26481/spe.20160422tk

Document Version:

Publisher's PDF, also known as Version of record

\section{Document license:}

Unspecified

\section{Please check the document version of this publication:}

- A submitted manuscript is the version of the article upon submission and before peer-review. There can be important differences between the submitted version and the official published version of record.

People interested in the research are advised to contact the author for the final version of the publication, or visit the DOI to the publisher's website.

- The final author version and the galley proof are versions of the publication after peer review.

- The final published version features the final layout of the paper including the volume, issue and page numbers.

Link to publication

\footnotetext{
General rights rights.

- You may freely distribute the URL identifying the publication in the public portal. please follow below link for the End User Agreement:

www.umlib.nl/taverne-license

Take down policy

If you believe that this document breaches copyright please contact us at:

repository@maastrichtuniversity.nl

providing details and we will investigate your claim.
}

Copyright and moral rights for the publications made accessible in the public portal are retained by the authors and/or other copyright owners and it is a condition of accessing publications that users recognise and abide by the legal requirements associated with these

- Users may download and print one copy of any publication from the public portal for the purpose of private study or research.

- You may not further distribute the material or use it for any profit-making activity or commercial gain

If the publication is distributed under the terms of Article $25 \mathrm{fa}$ of the Dutch Copyright Act, indicated by the "Taverne" license above, 


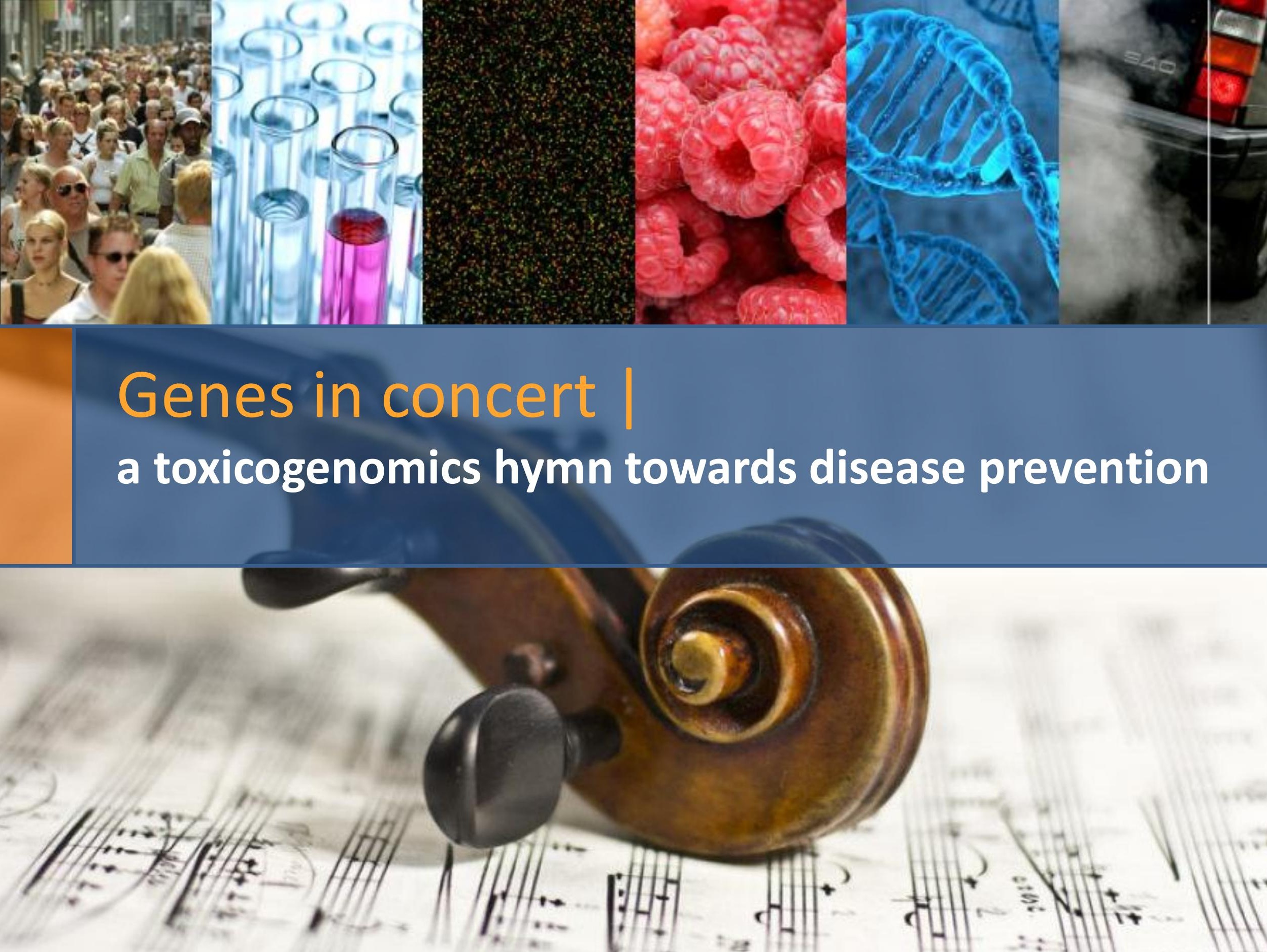




\section{Toxicological research}

\section{A world full of potential hazards}
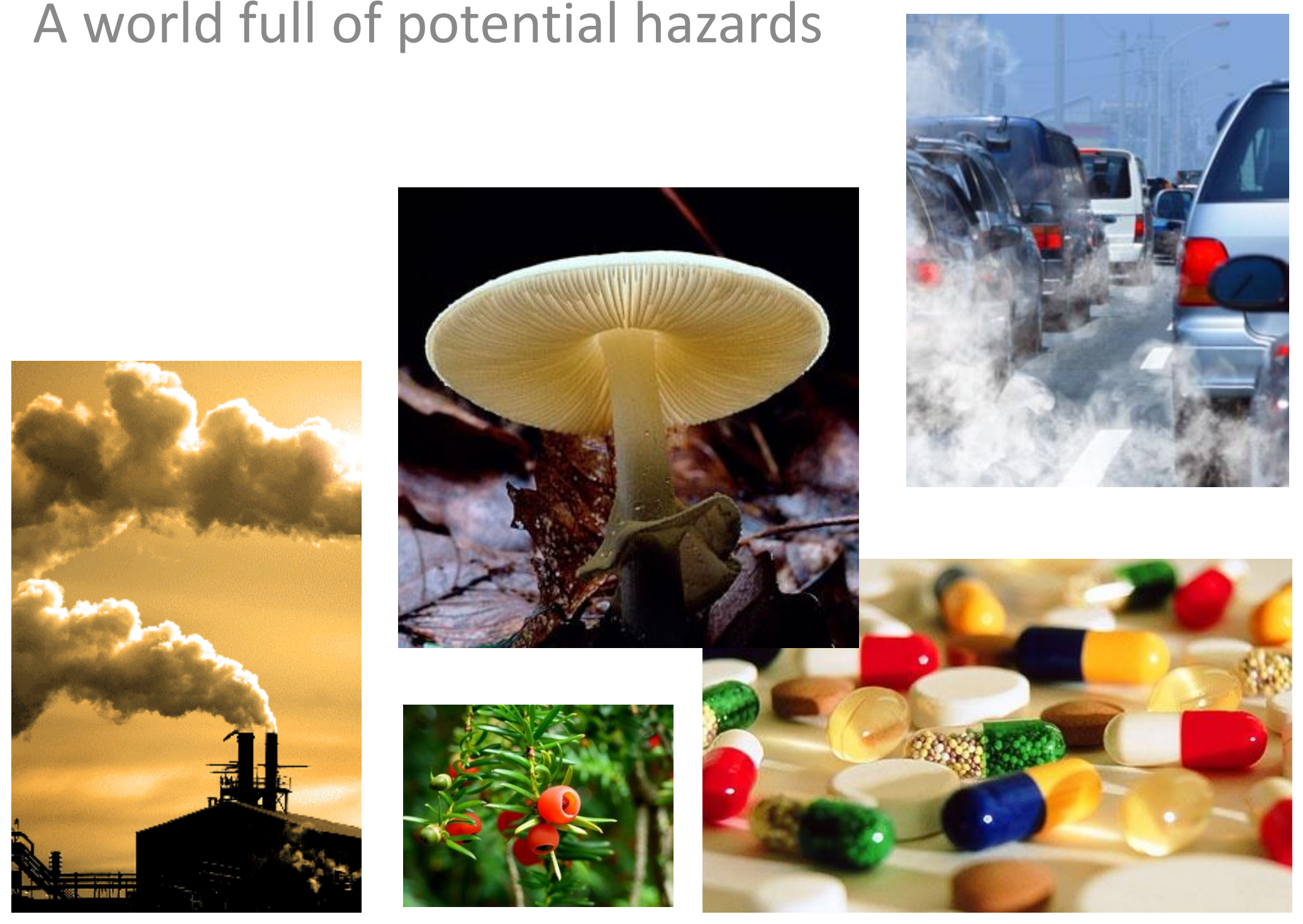


\section{Toxicological research}

Human studies: the Praegustator

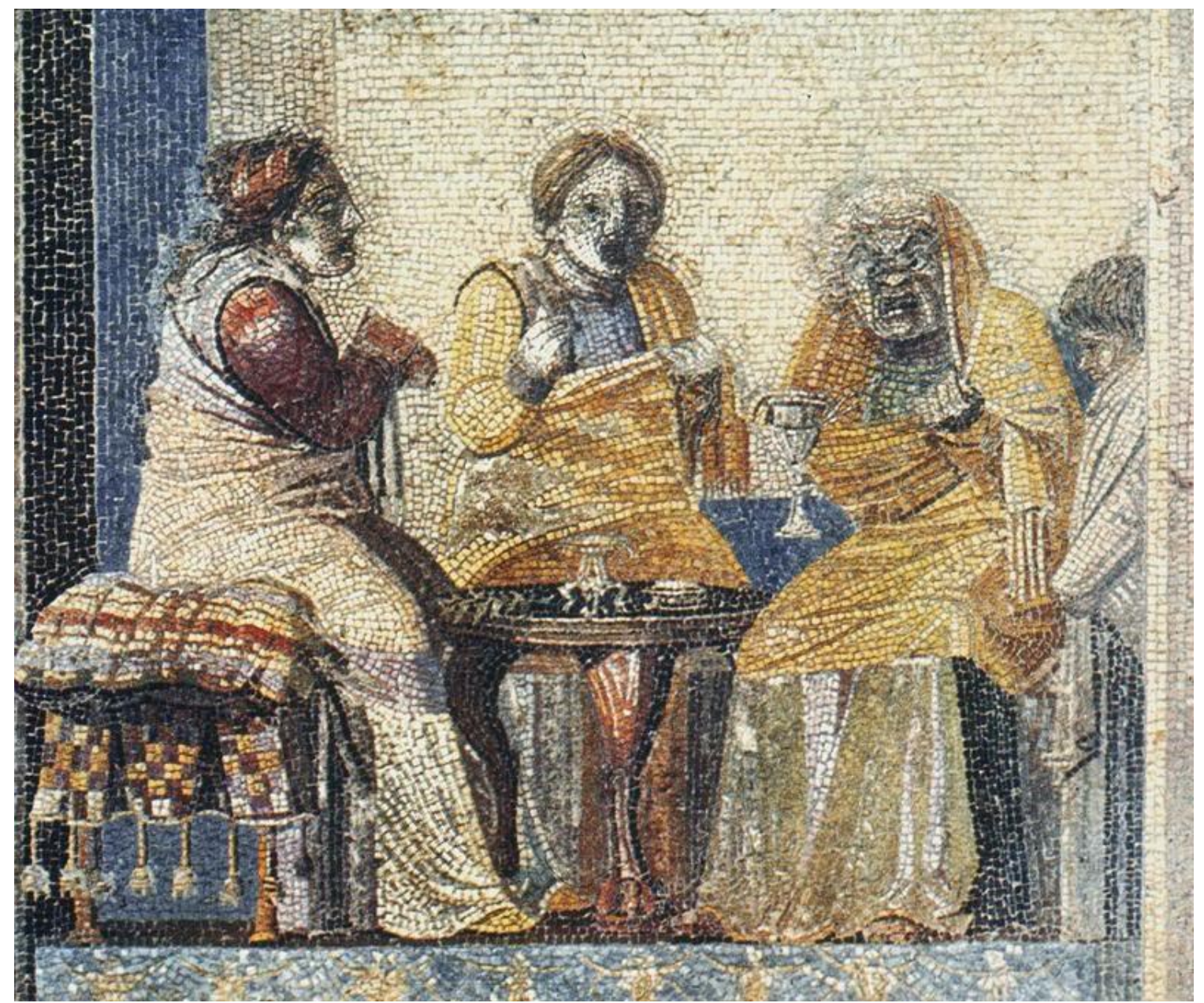




\section{Toxicological research}

Cell cultures as alternative to animals as alternative for humans
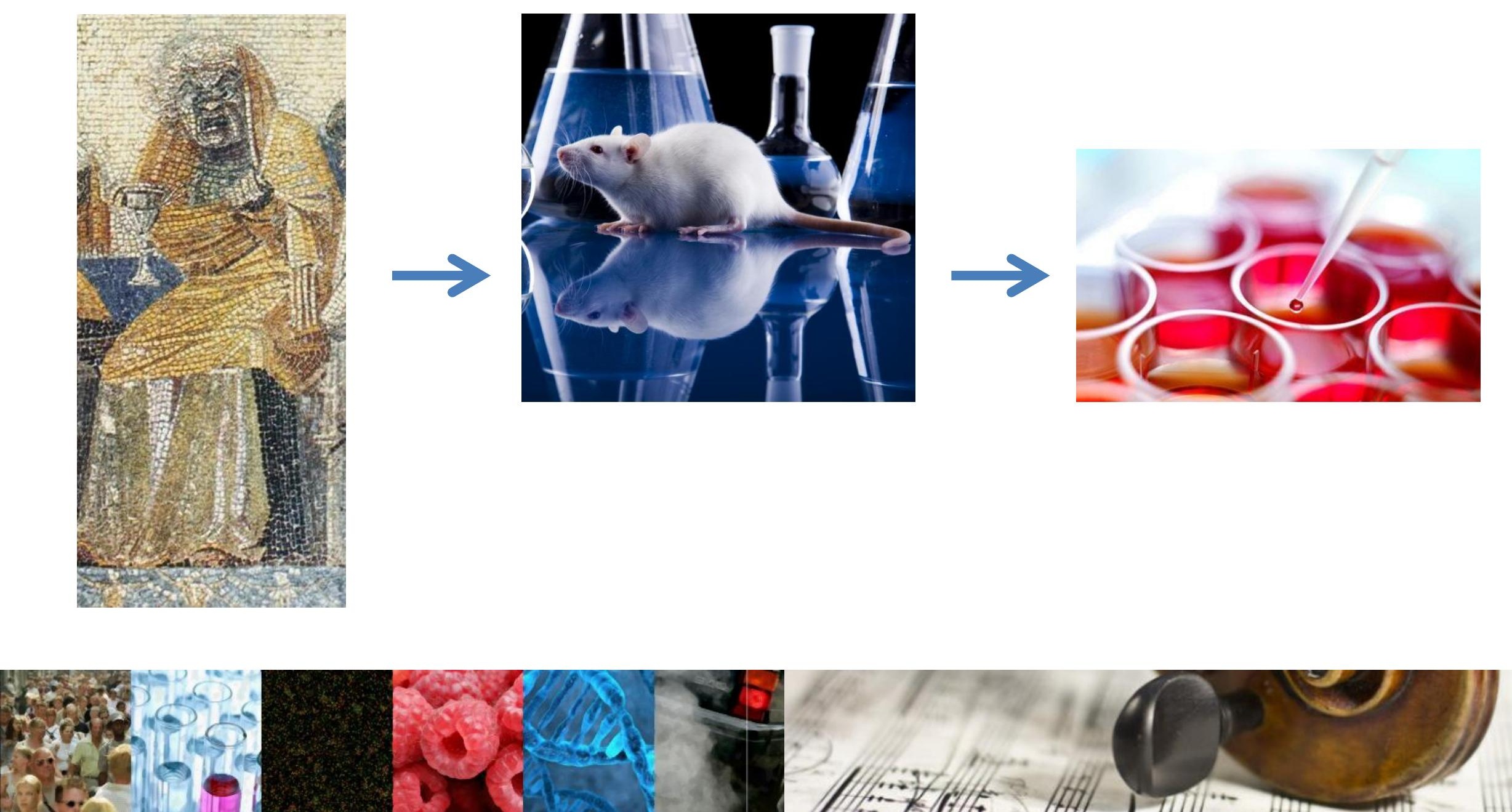


\section{Toxicogenomics}

A revolution initiated by the human genome project
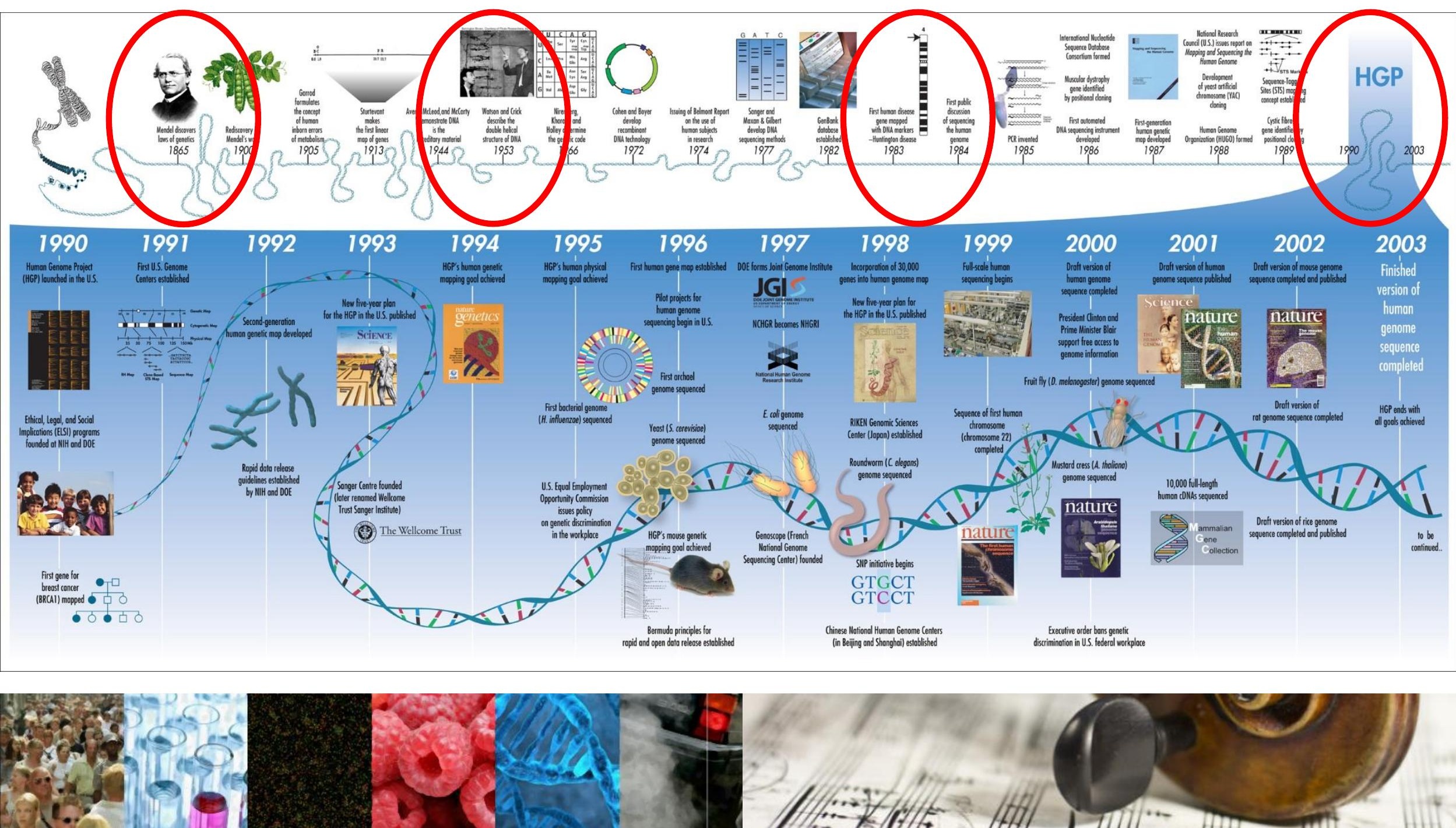


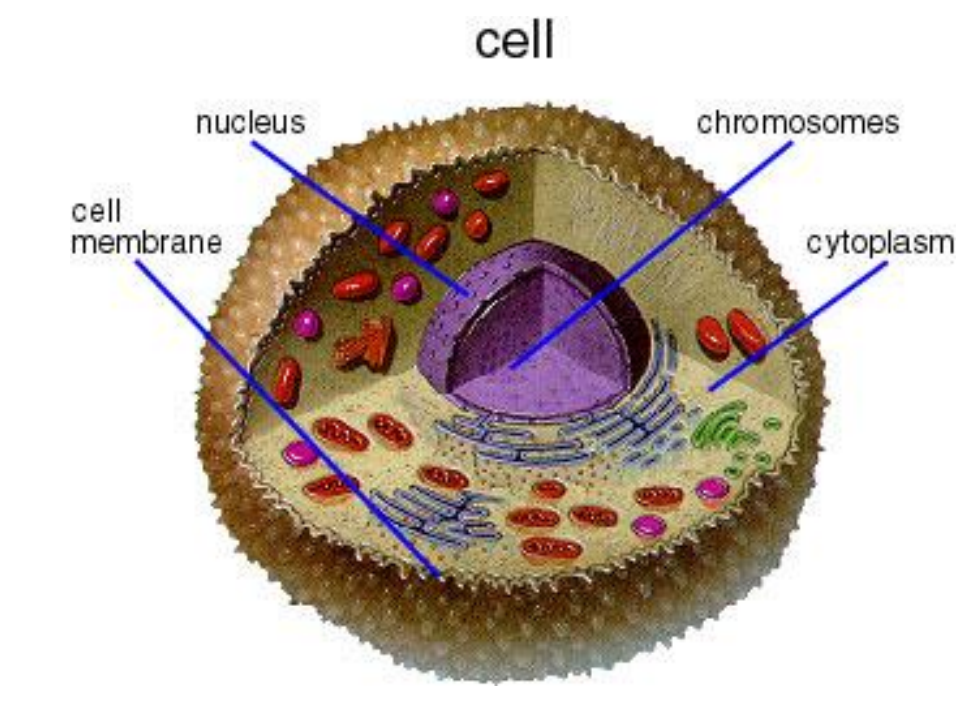

\section{Toxicant}

DNA $\longrightarrow$ RNA $\longrightarrow$ Proteins $\longrightarrow$ Metabolites
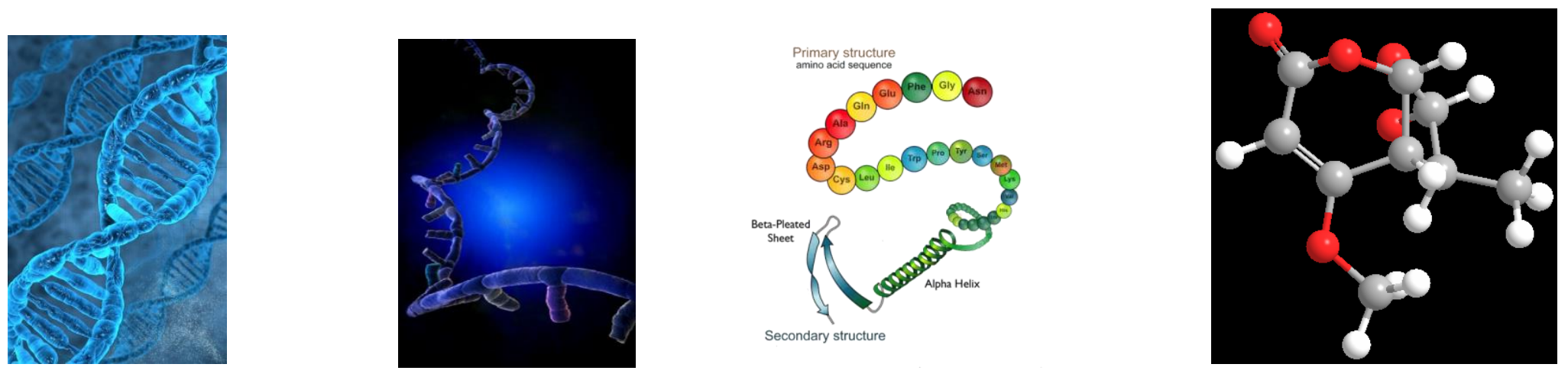

Elimination 

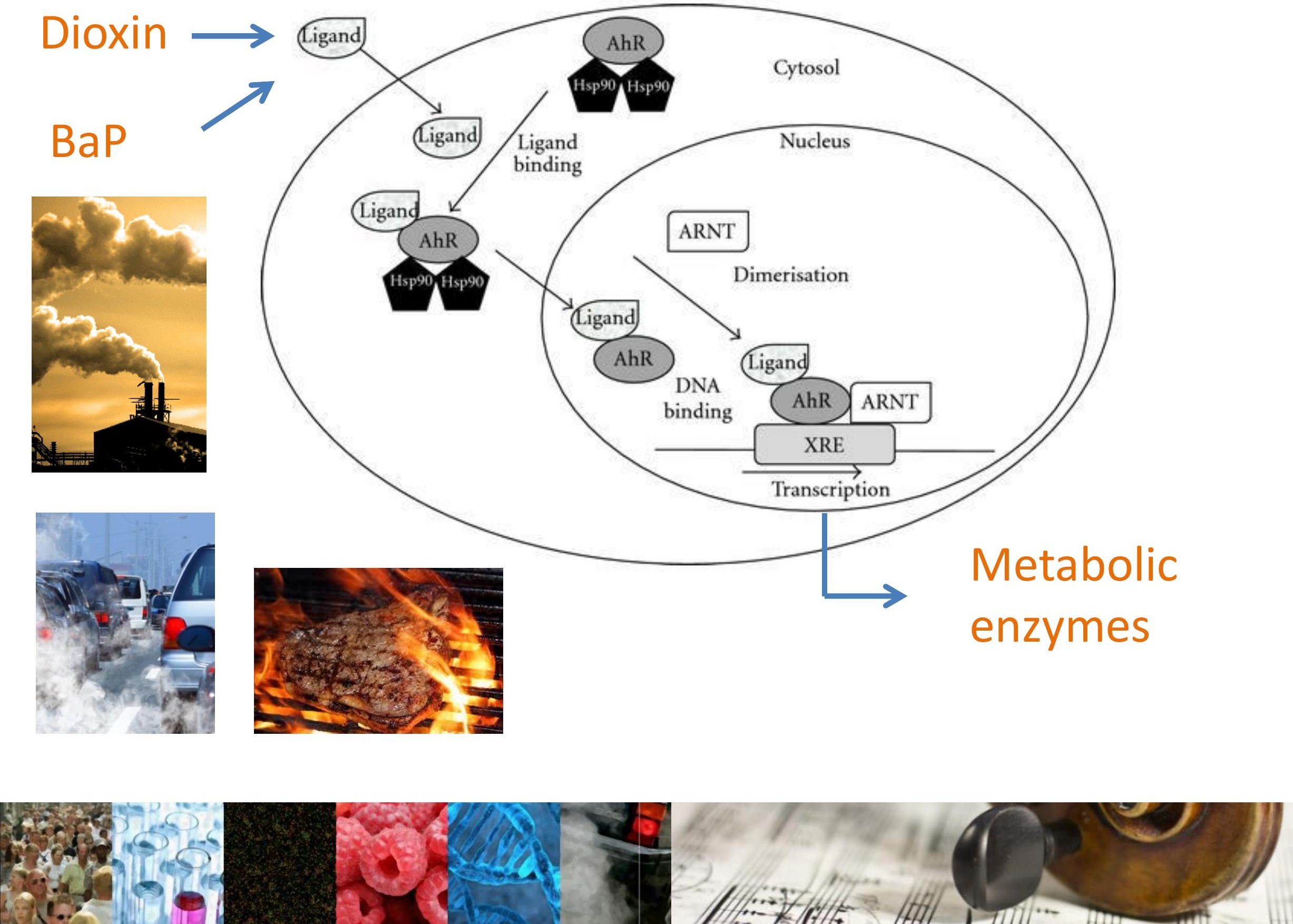


\section{Gene expression profiles:}

a barcode for potential toxicity
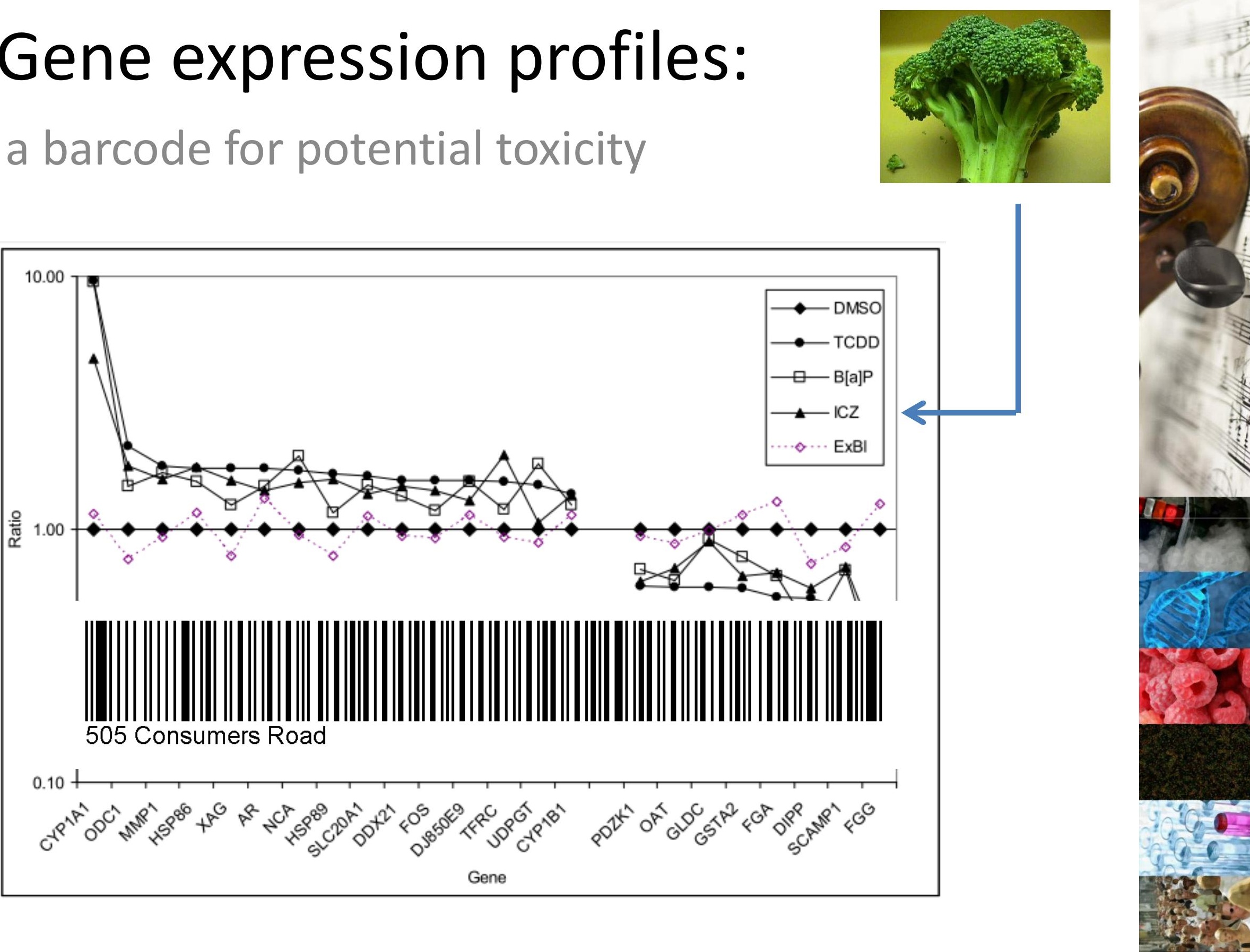


\section{Genes in concert}

How to interpret gene expression profiles
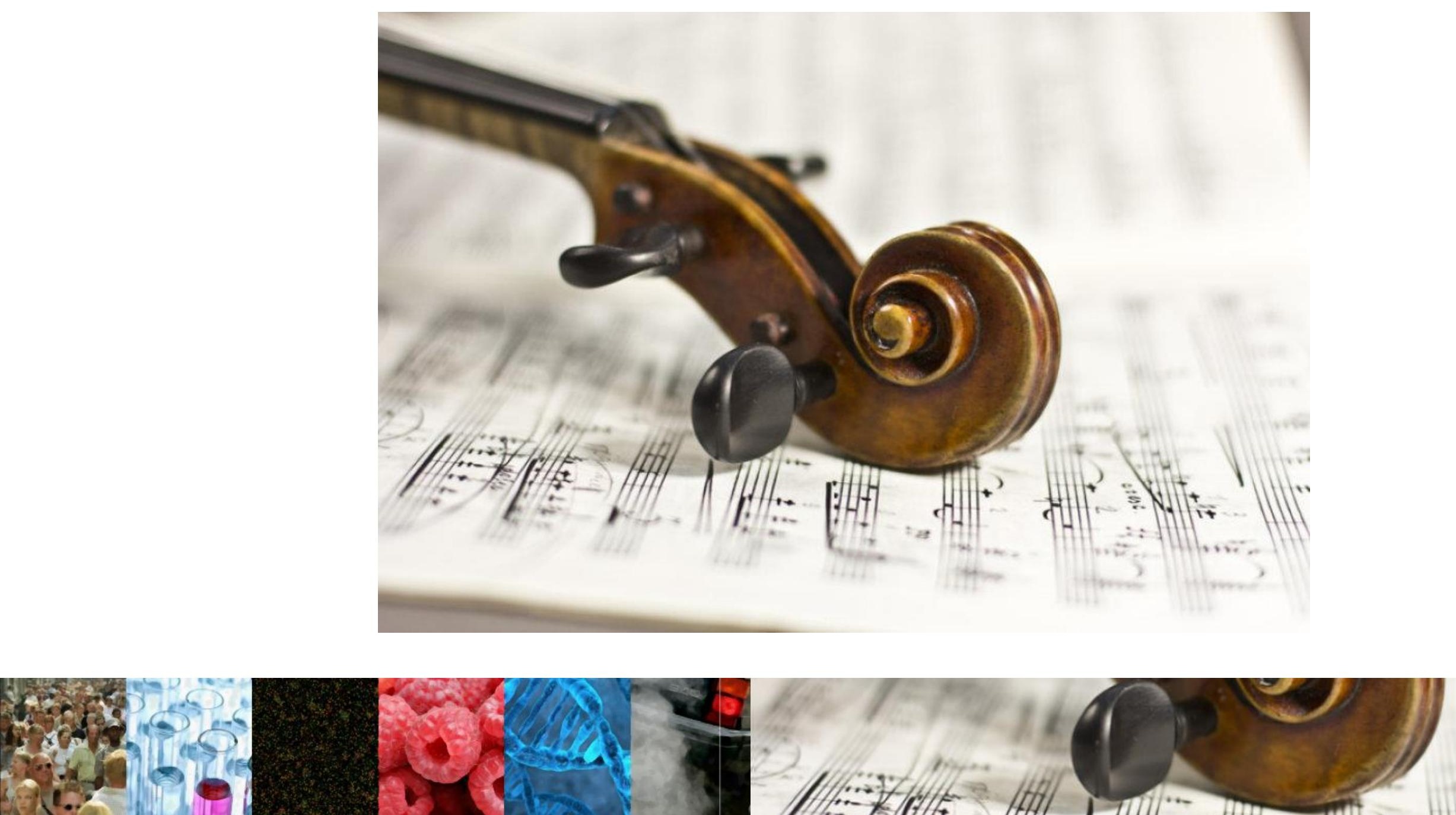


\section{Human population studies}

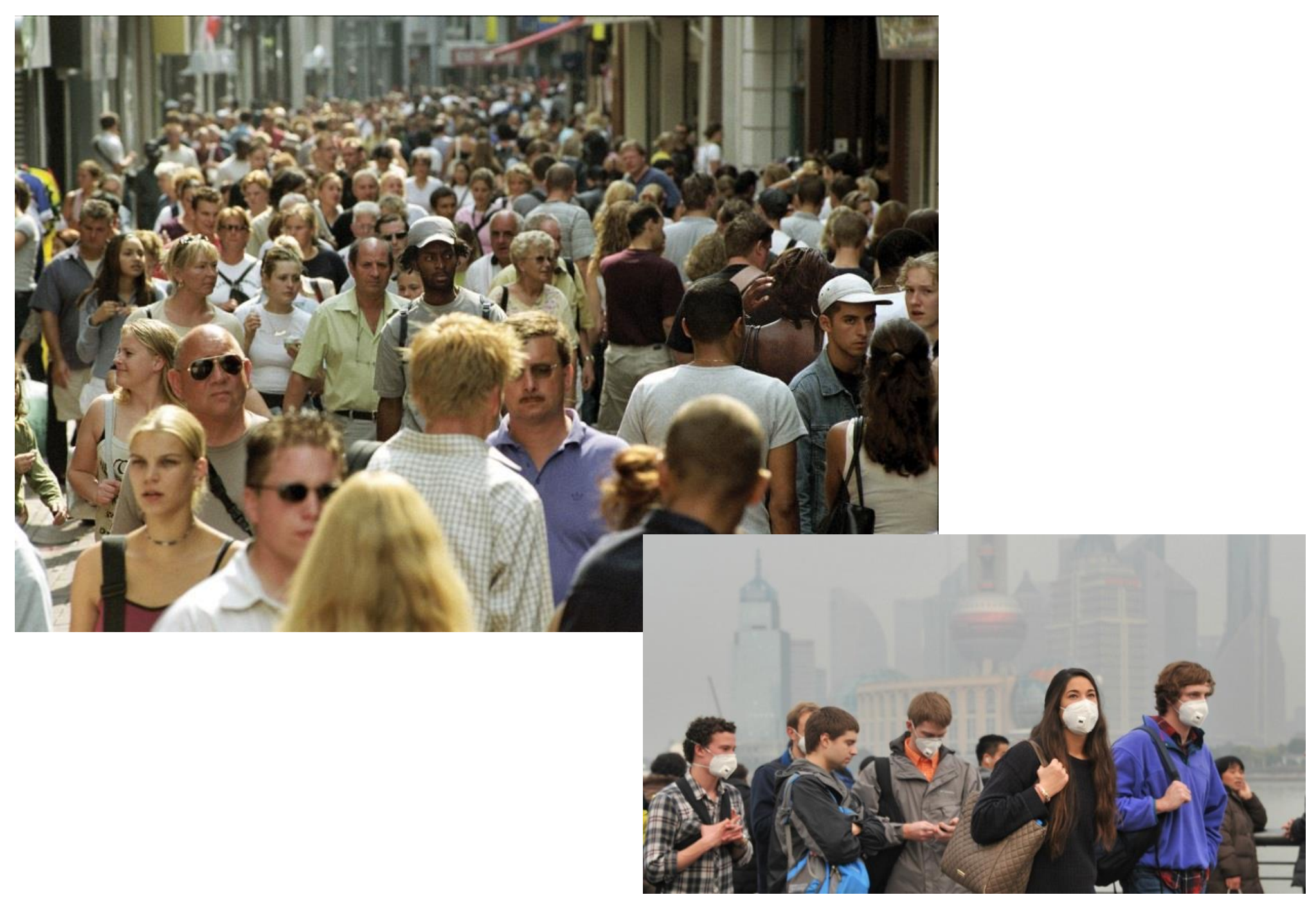




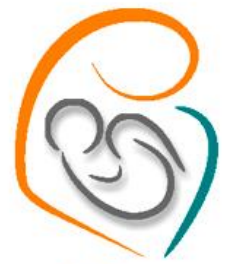

NewGeneris

Newborns and Genotoxic exposure risks

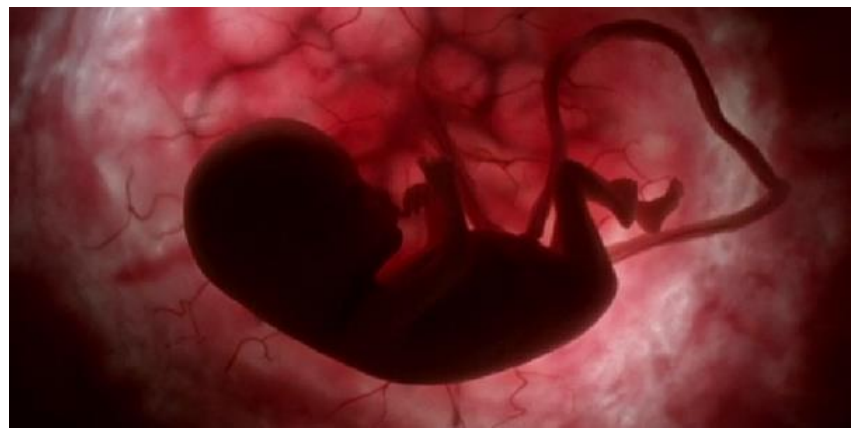

Lymphoid leukaemia in children

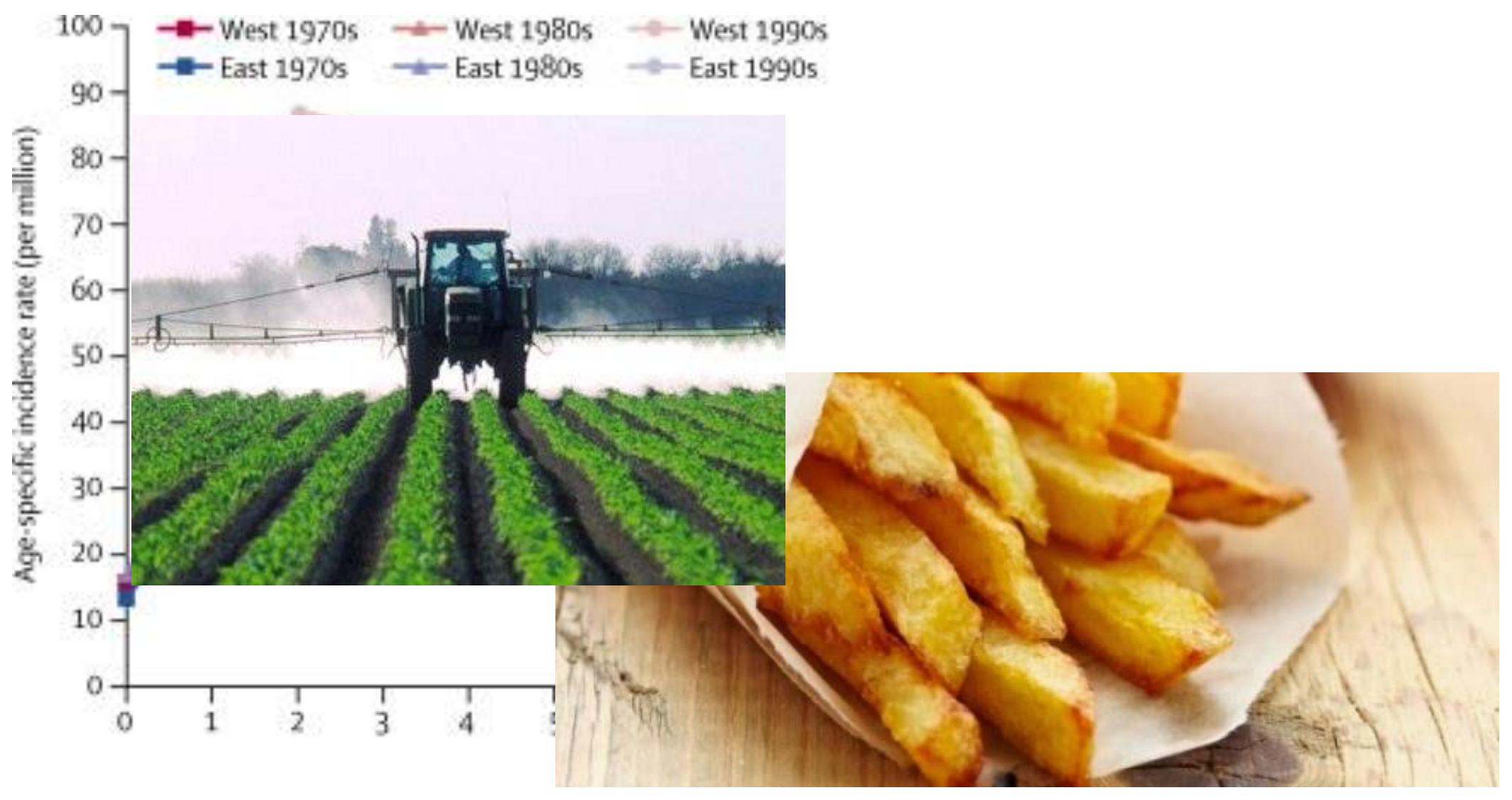




\section{- id envirogenomarkers}

GENOMICS BIOMARKERS OF ENVIRONMENTAL HEALTH
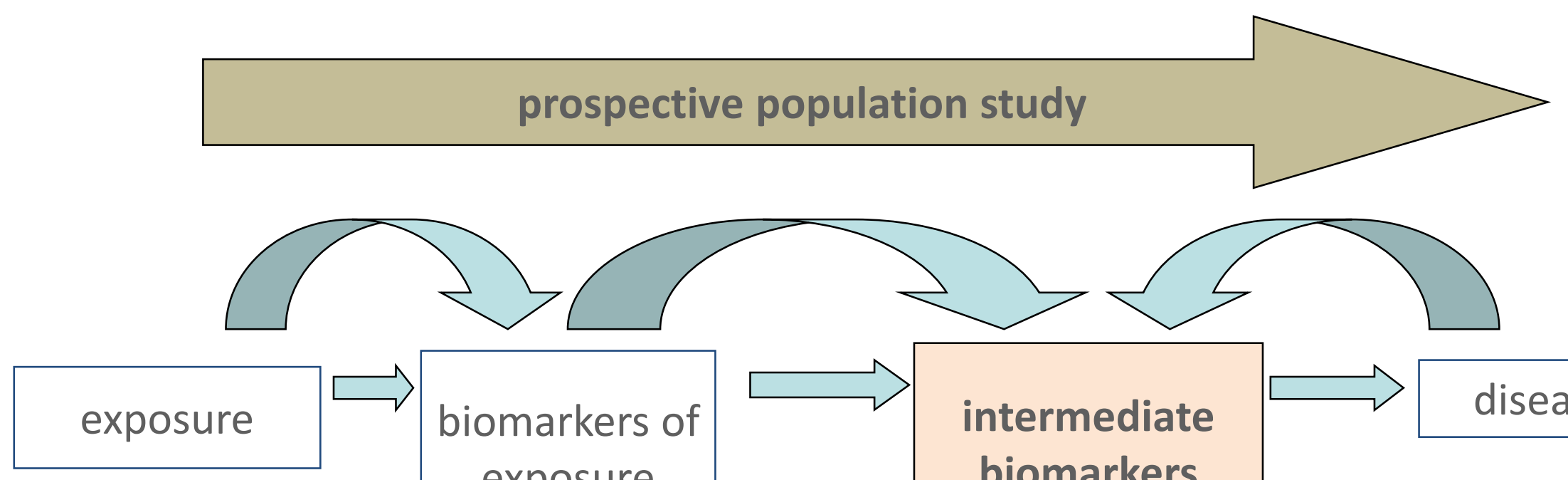

biomarkers of exposure

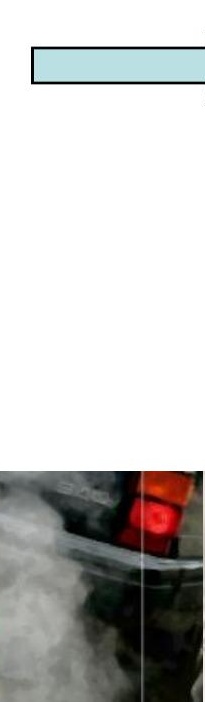
intermediate

disease biomarkers 


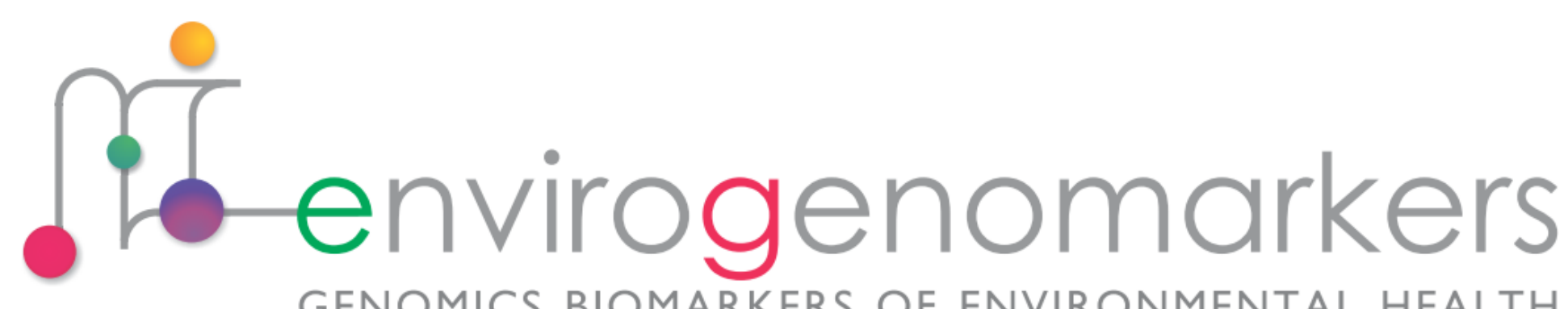

GENOMICS BIOMARKERS OF ENVIRONMENTAL HEALTH

\section{Chronic lymphocytic leukemia}
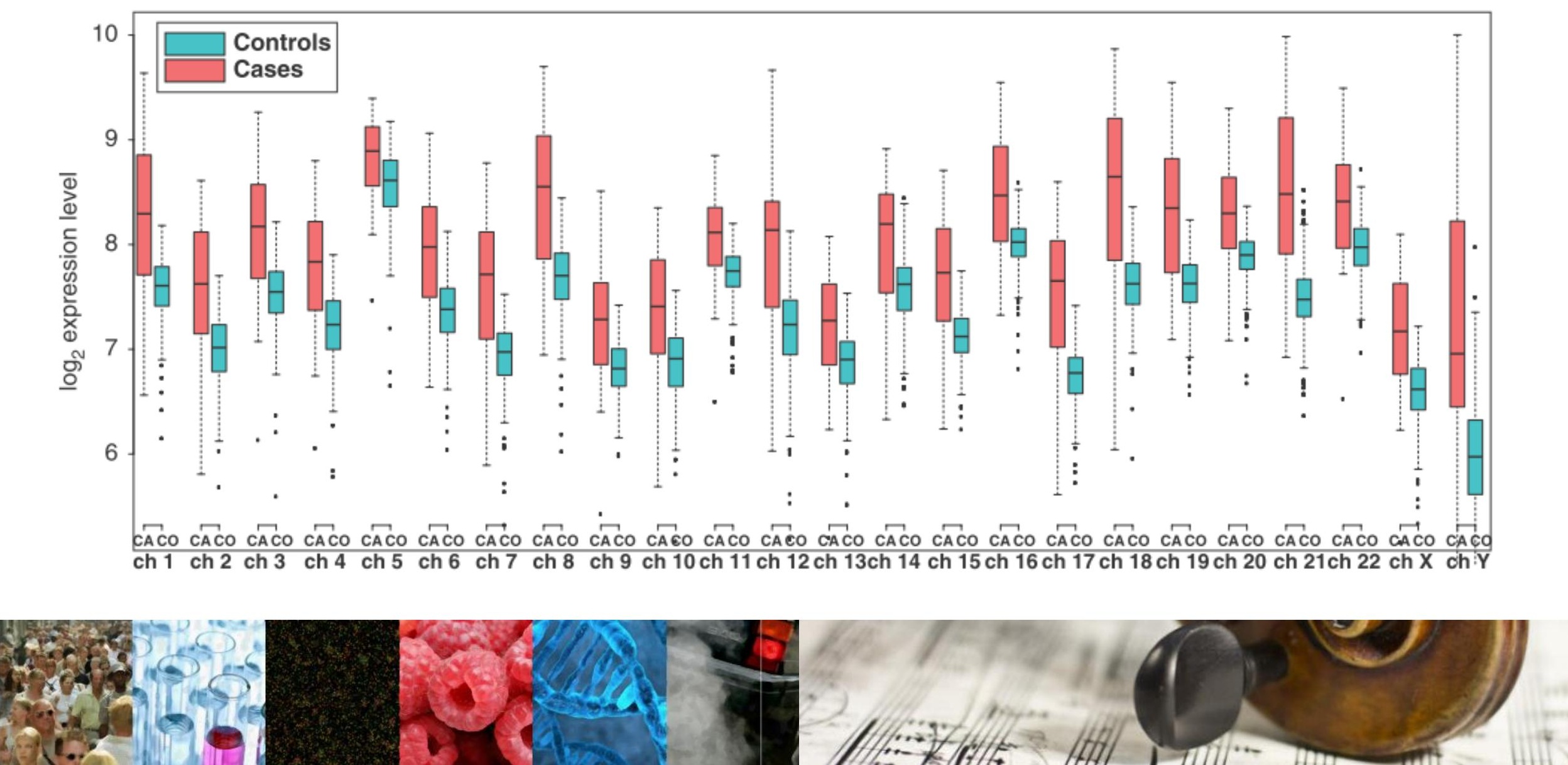


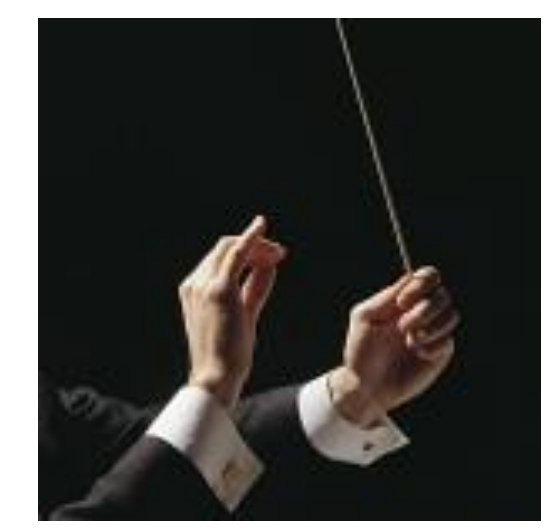

methylation miRNA protein degradation

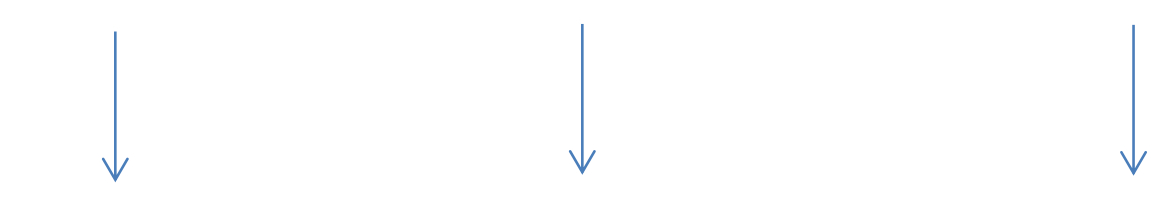

DNA $\longrightarrow$ RNA $\longrightarrow$ Proteins $\longrightarrow$ Metabolites
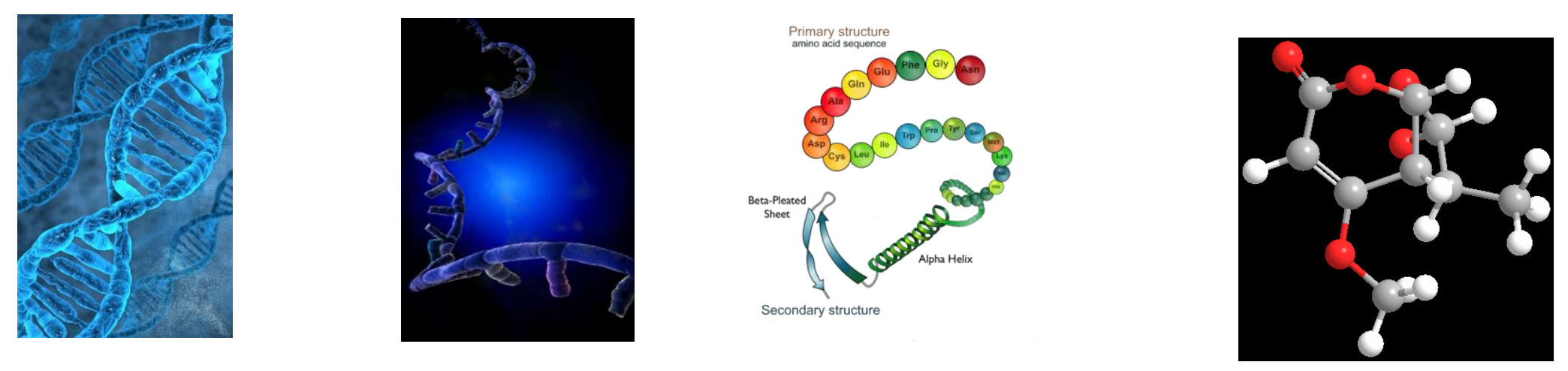

60 40 
Smoking as proof-of-principle
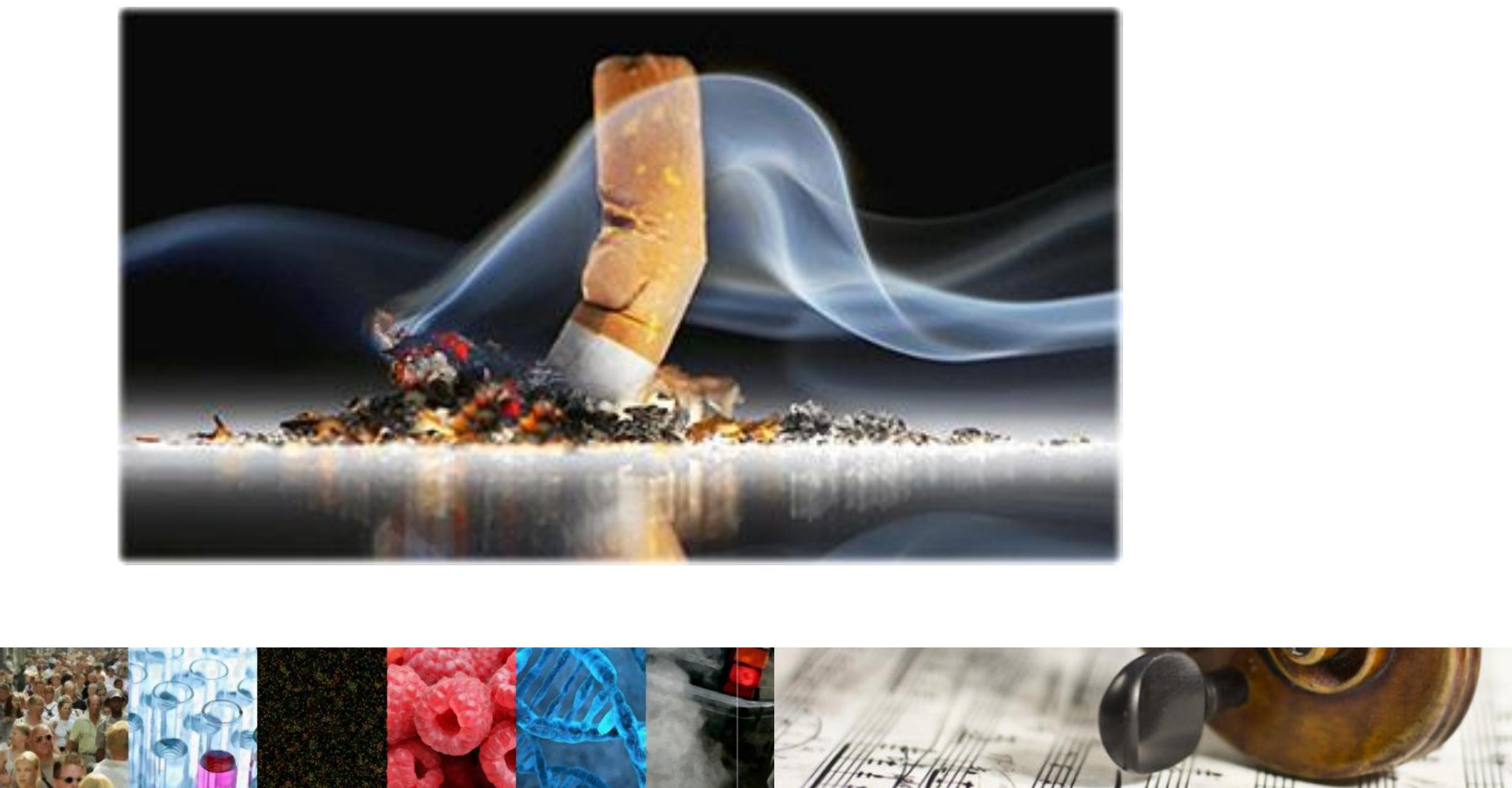


\section{. 10 envirogenomarkers}

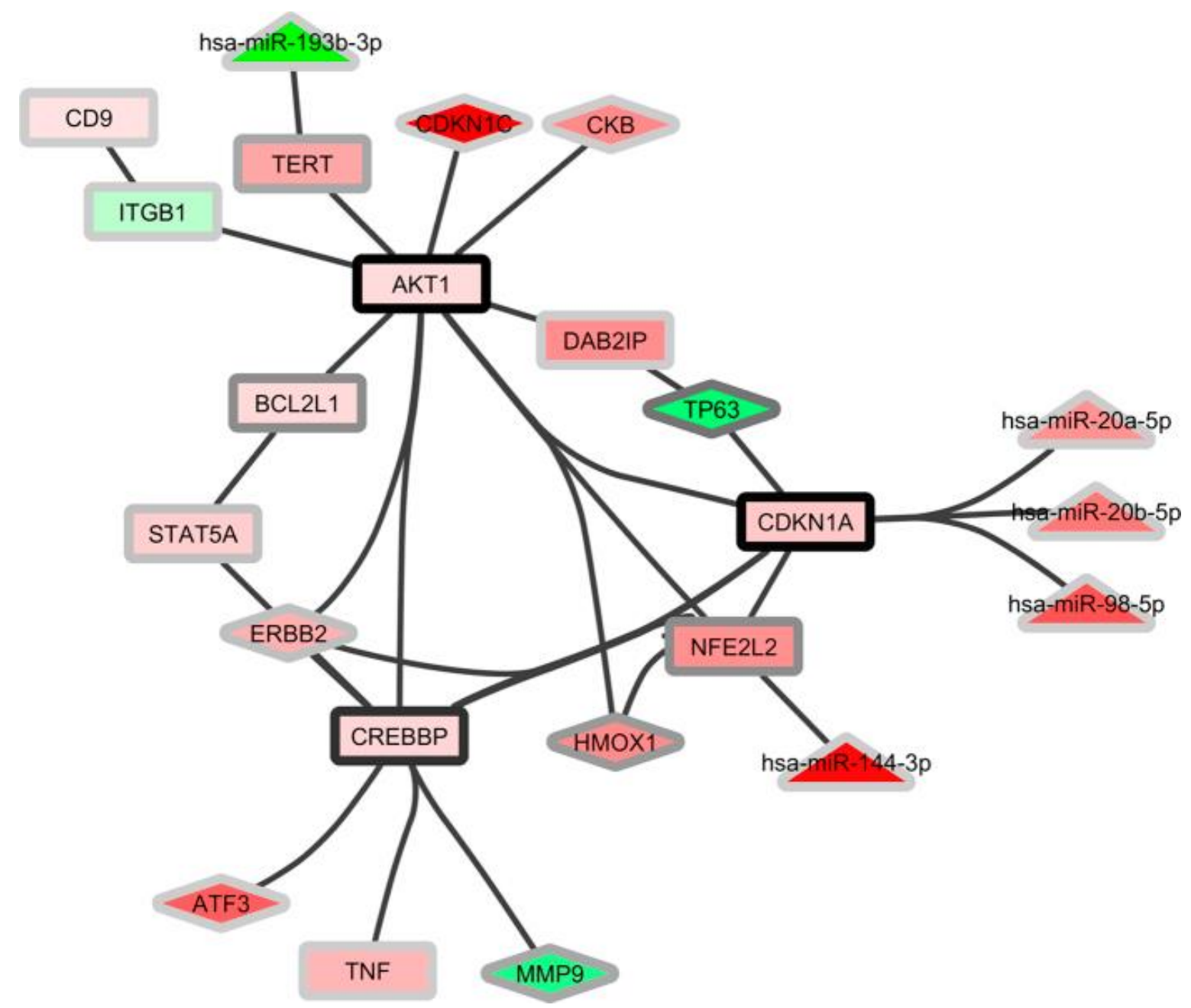




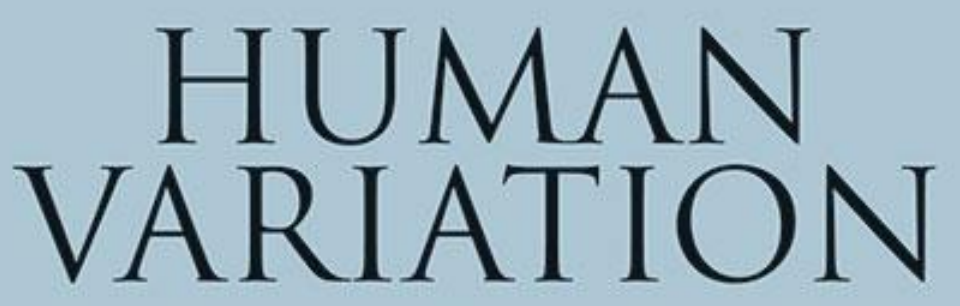

A Genetic Perspective on Diversity, Race, and Medicine

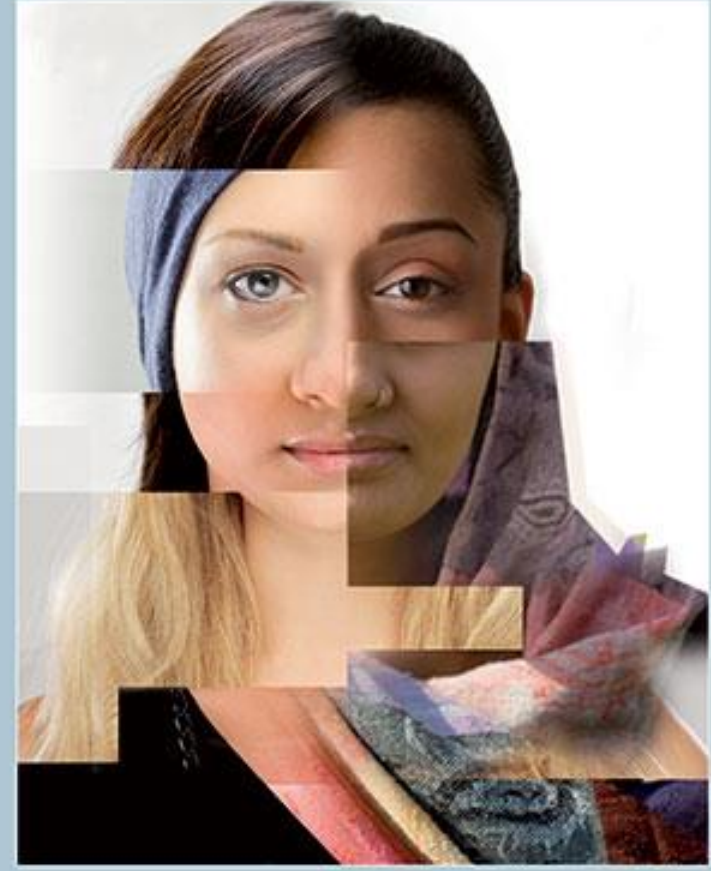

Edito

ARAVINDA CHAKRAVARTI

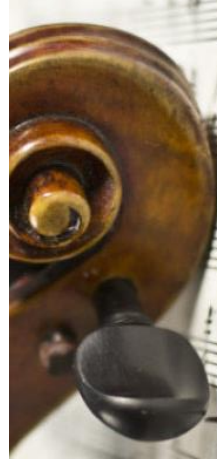

Genetic polymorphisms

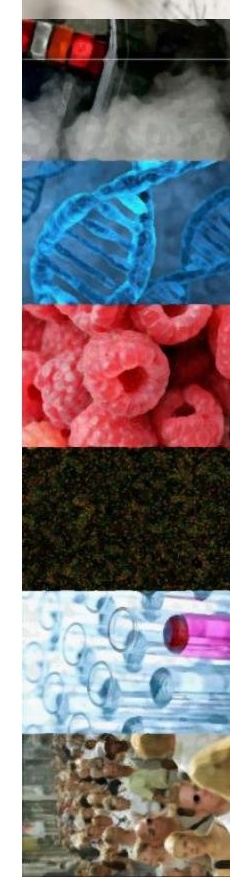




\section{Prediction}
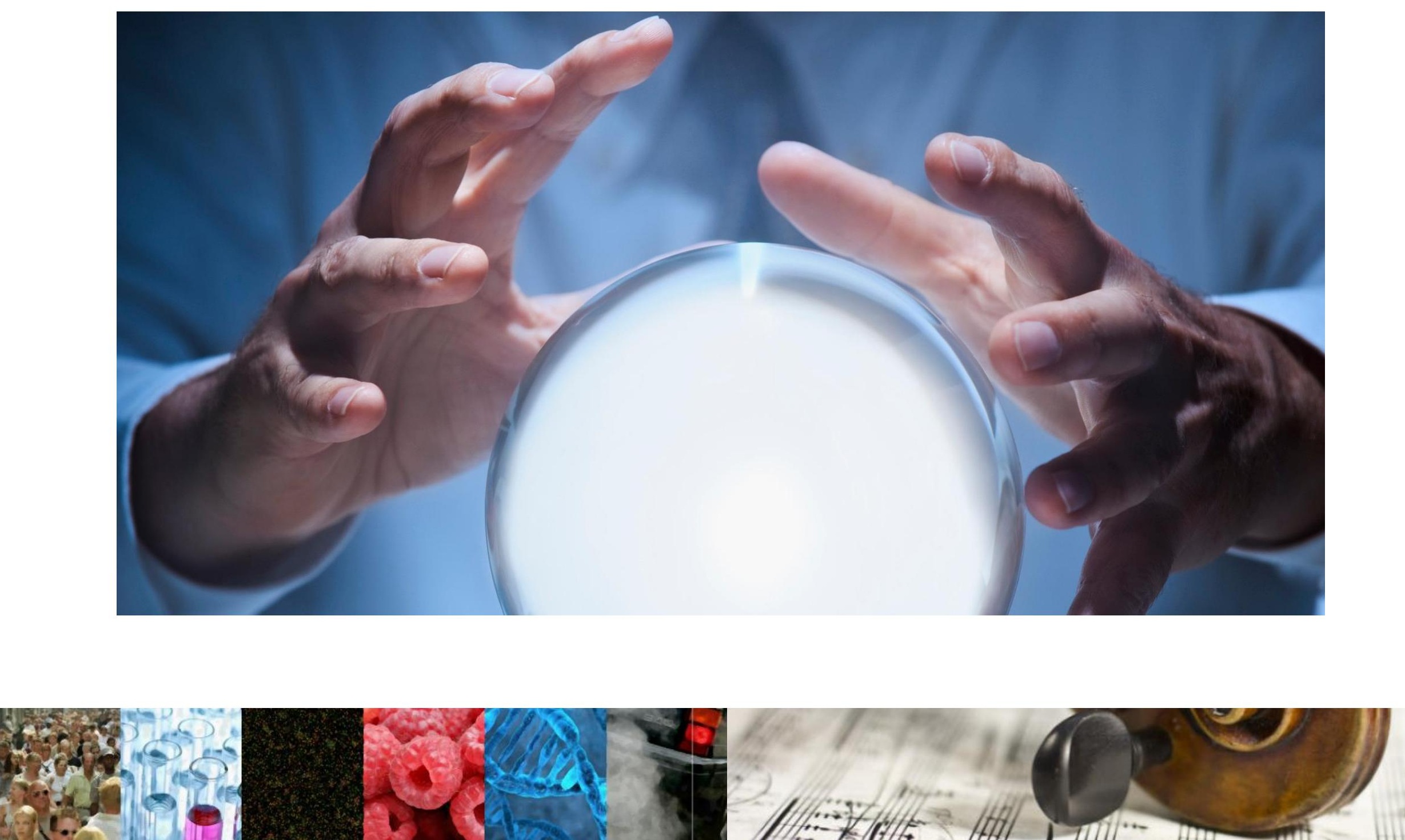


\section{Prediction}
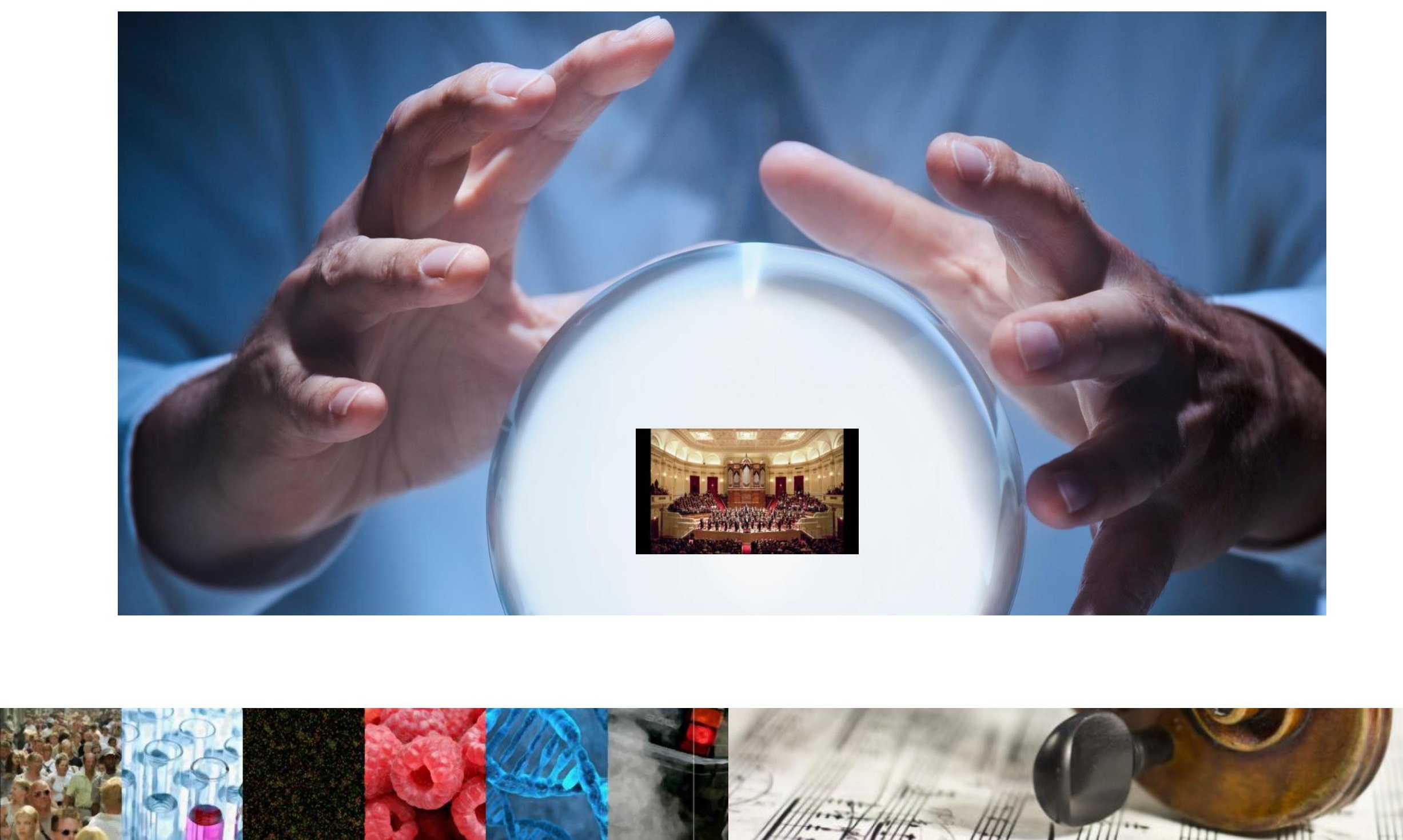


\section{Prediction: the national hymn}
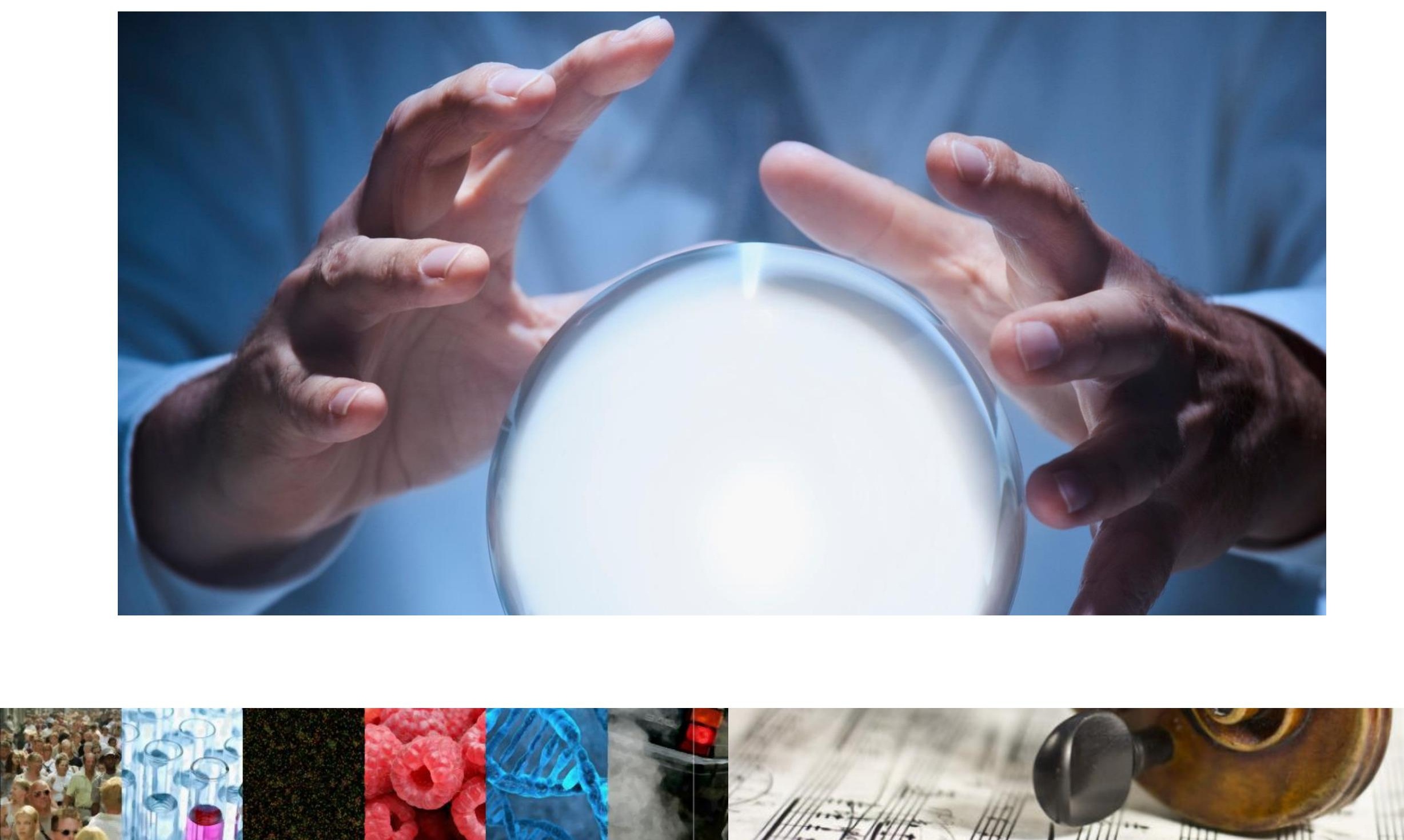


\section{Environmental Health studies}

\section{.0ْ- envirogenomarkers}

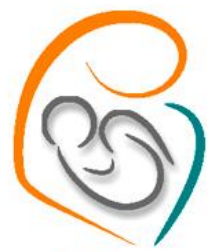

NewGeneris

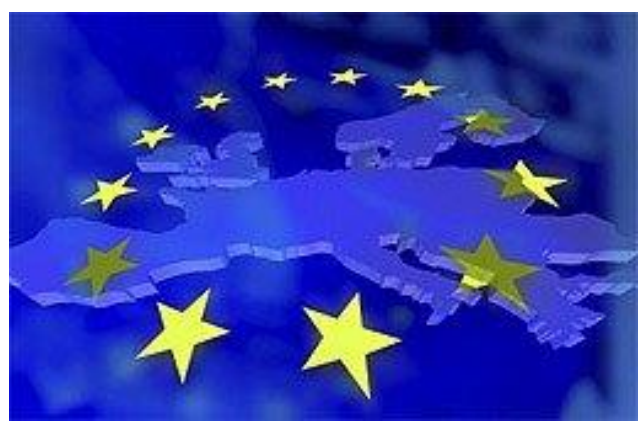

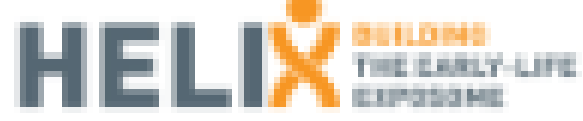

Newborns and Genotoxic exposure risks

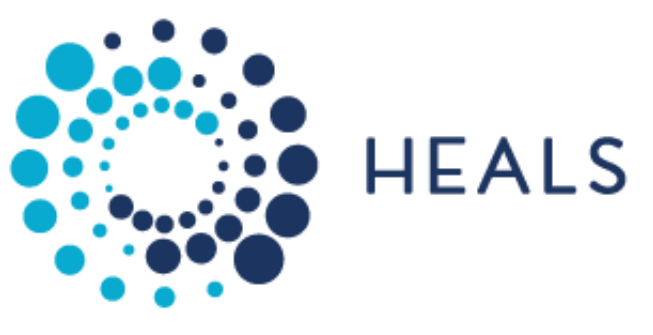

expos

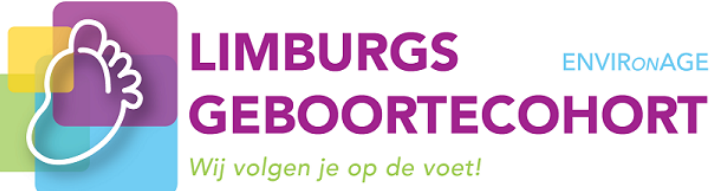

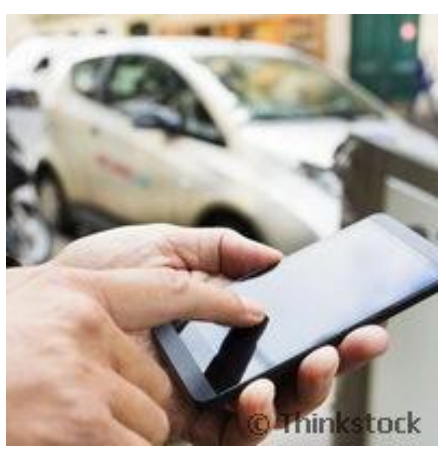




\section{Multidisciplinary research}

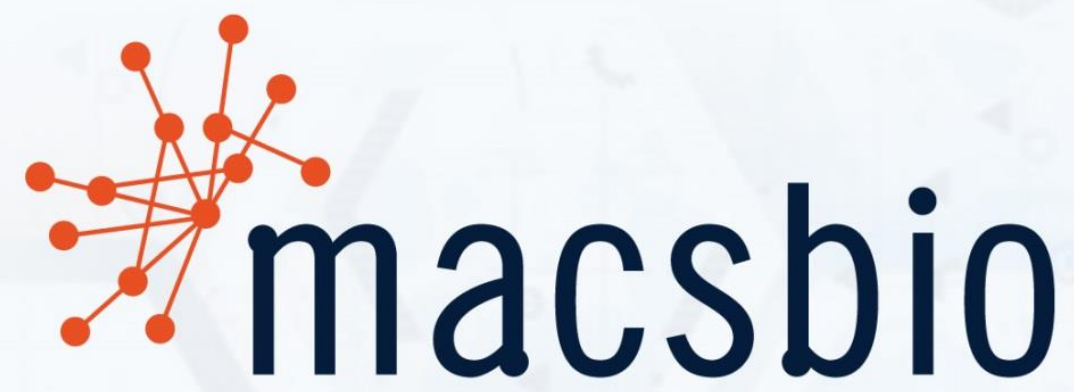

MAASTRICHT CENTRE FOR SYSTEMS BIOLOGY

\section{Science Day 2016}

\section{May 17 $7^{\text {th }}, 2016$}

Maastricht - The Netherlands 


\section{Prevent readmission \\ System change integrate change \\ Treating whole person \\ Help patients \\ nutrition education \\ Community structure for healthy lifestyle}

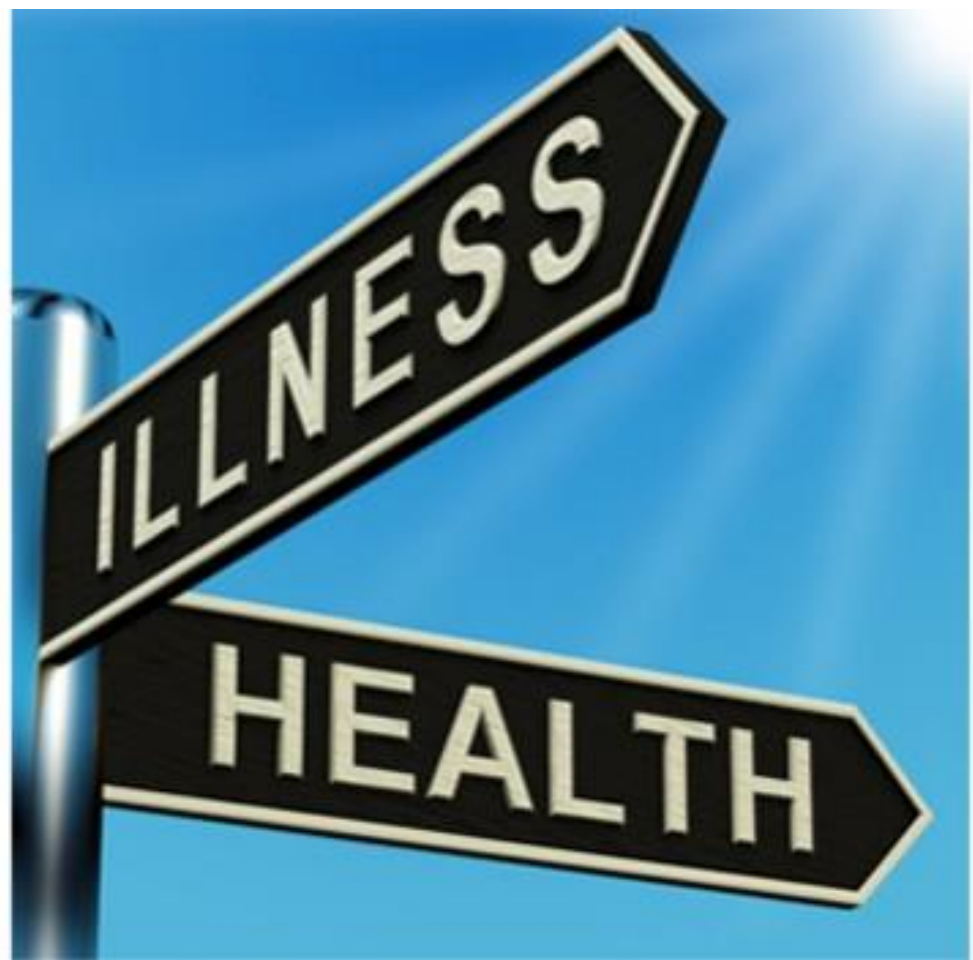




\title{
Ж American Institute for  Cancer Research
}

\author{
supports the
}

International Agency for Research on Cancer

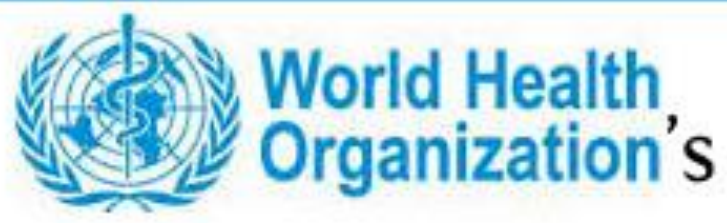

classification of processed meat as "carcinogenic to humans." 


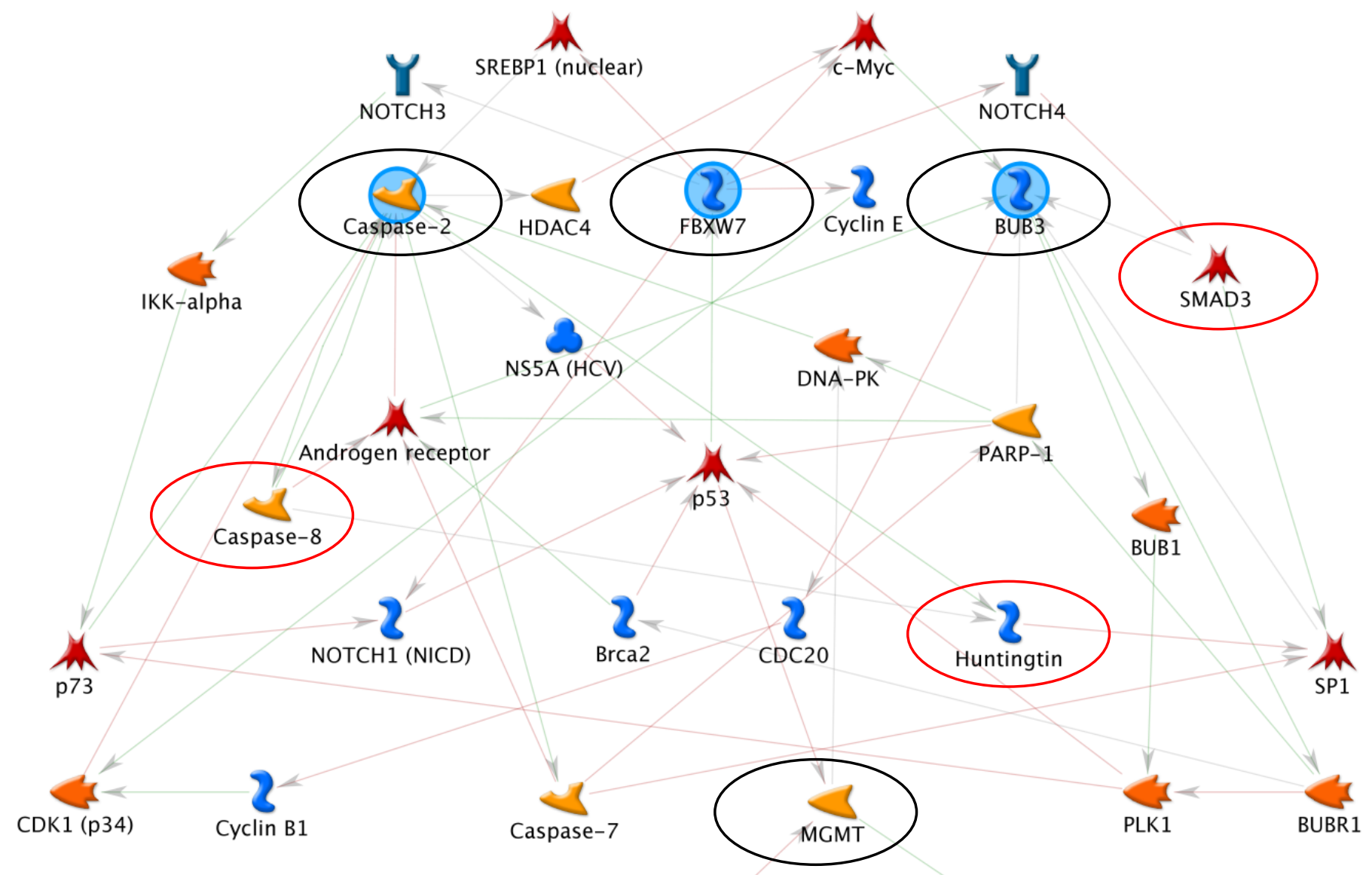

\section{Exposure



Dagblad De Limburger / Limburgs Dagblad.

Dinsdag, 08 december 2015

\section{Groene thee in de}

\section{Salami!}

Onderzoekers van de Universiteit Maastricht (UM) en collega's in Europa hebben drie jaar gewerkt aan 'veilige' worst, ham en andere vleeswaren zónder extra risico's op darmkanker. Hoogleraar Theo de Kok van de UM geeft een kijkje in de keuken.

\section{PHYTOME}

Phytochemicals to reduce nitrite in meat products

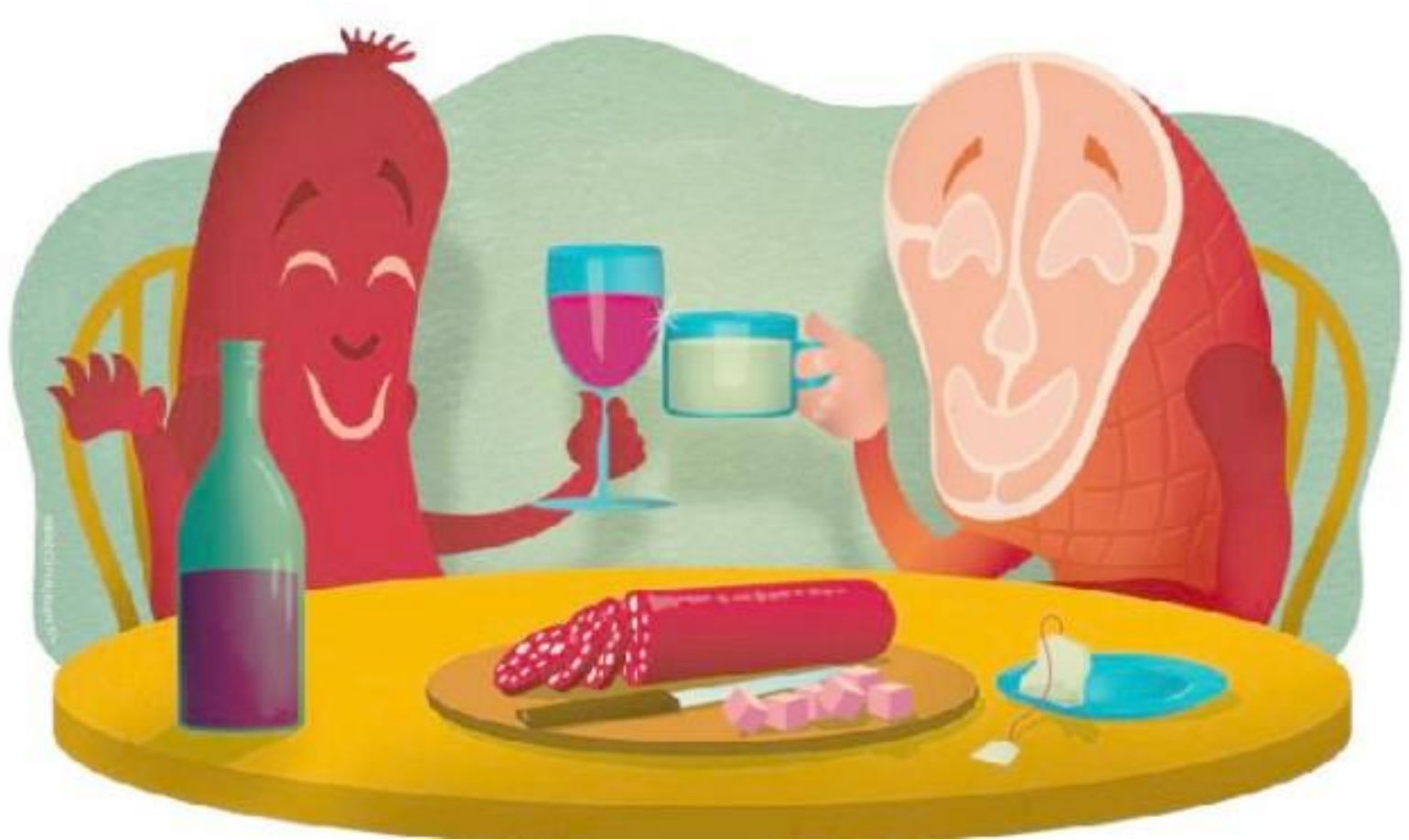




\section{PHYTOME}

Phytochemicals to reduce

nitrite in meat products
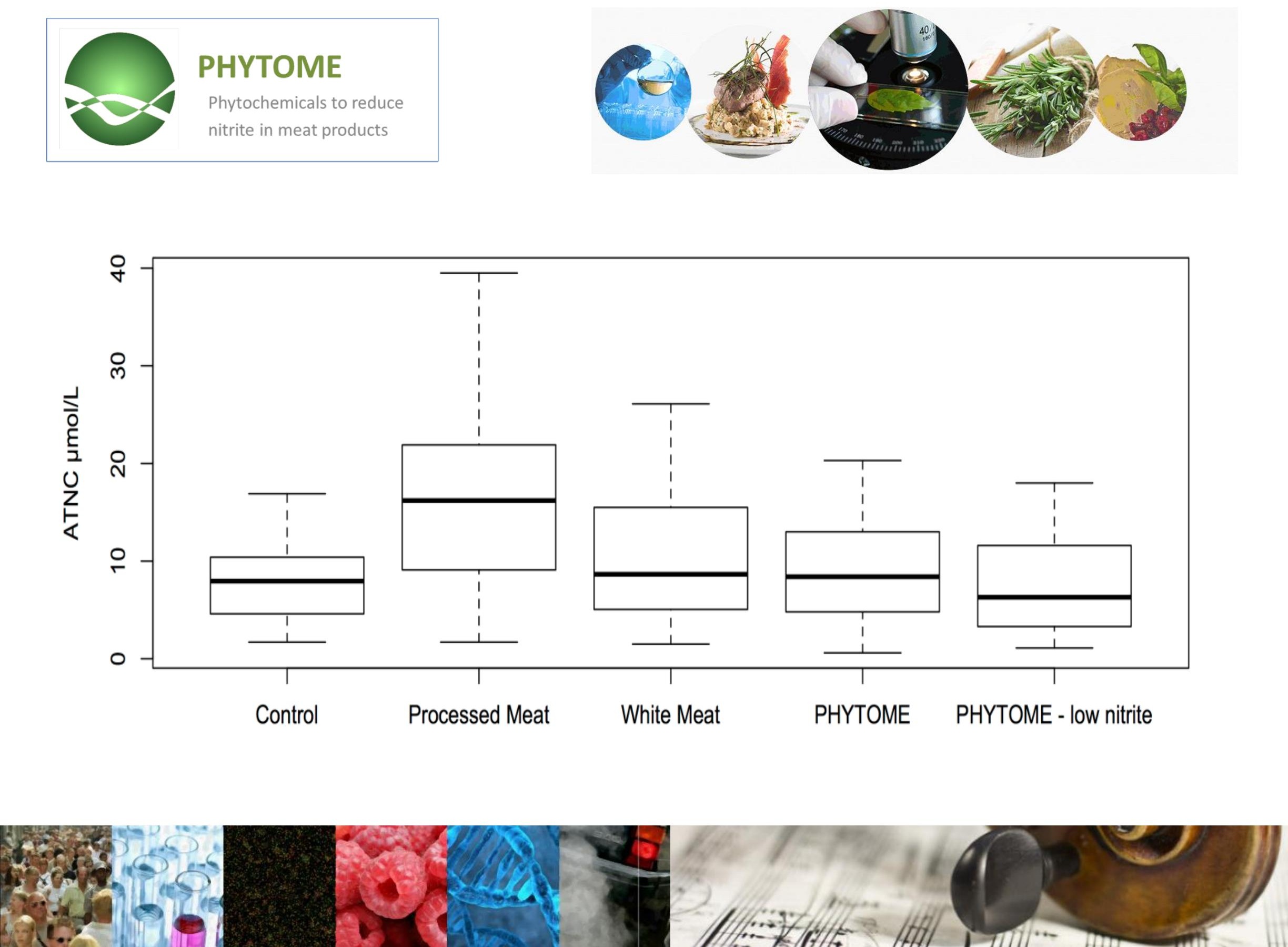


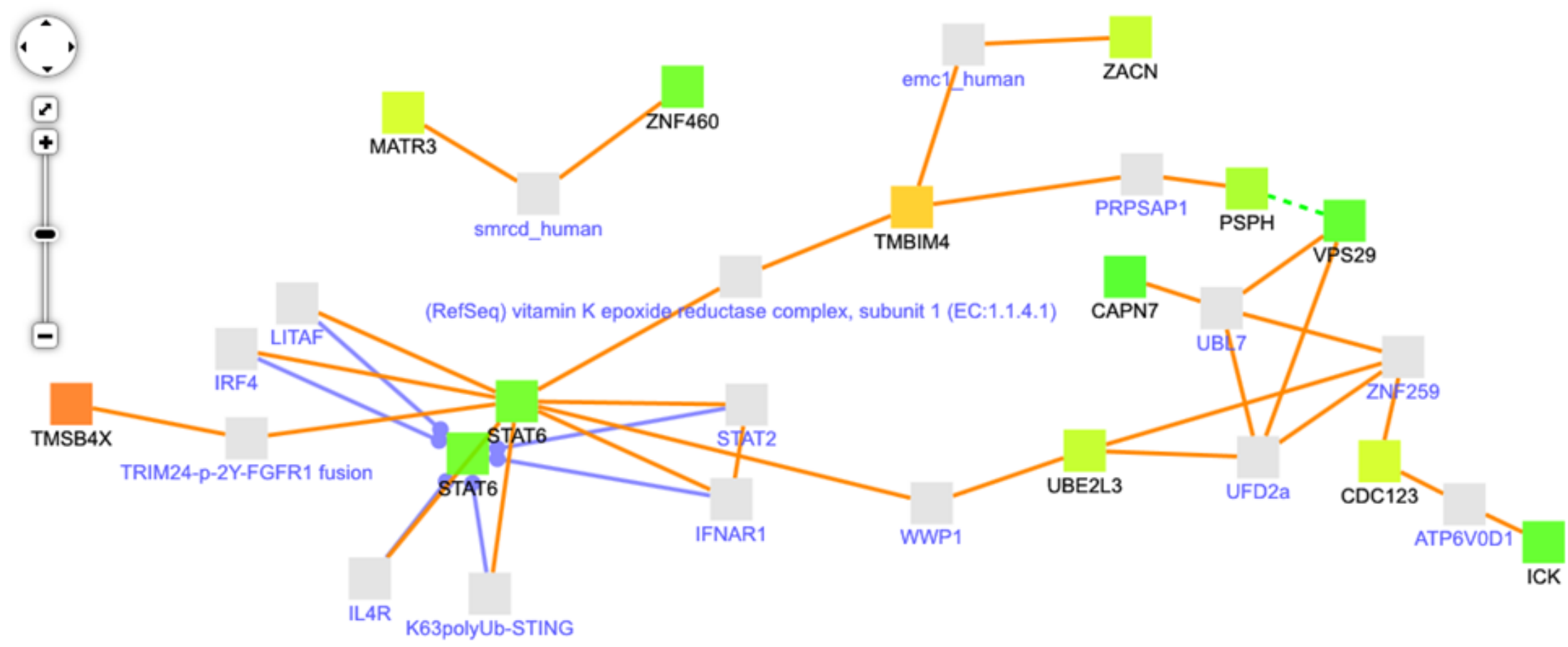

\section{'hysical entity color Interaction color}

$\begin{array}{ll}-0.025 & - \text { protein interaction } \\ -0.012 & - \text { genetic interaction } \\ 0 & - \text { biochemical reaction } \\ 0.012 & - \text { gene regulatory interaction } \\ 0.025 & \text { drug-target interaction }\end{array}$

\section{Node label color}

black node labels denote seed nodes

Hide legend

purple node labels denote

intermediate nodes

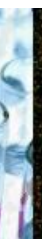
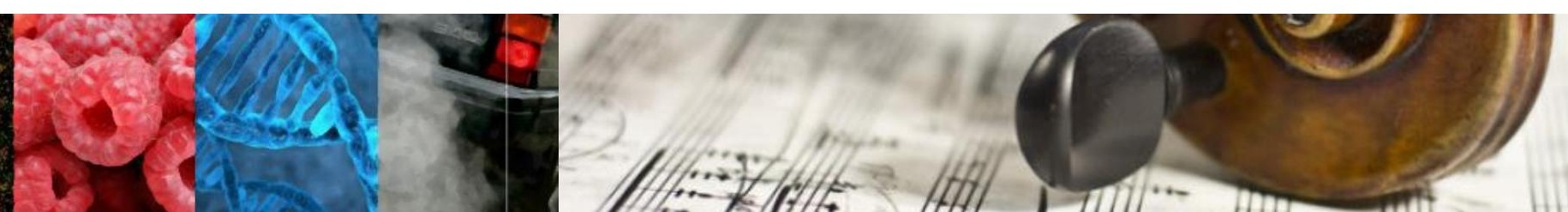

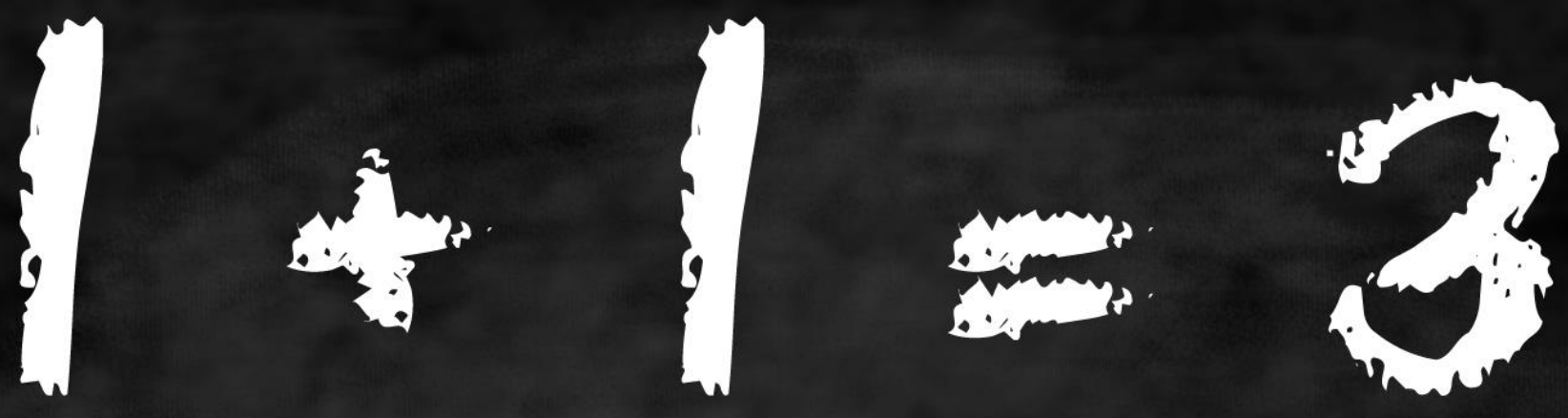

A GUIDE TO FOOD SYMERGY

How 2 foods paired together can increase nutritional benefits 

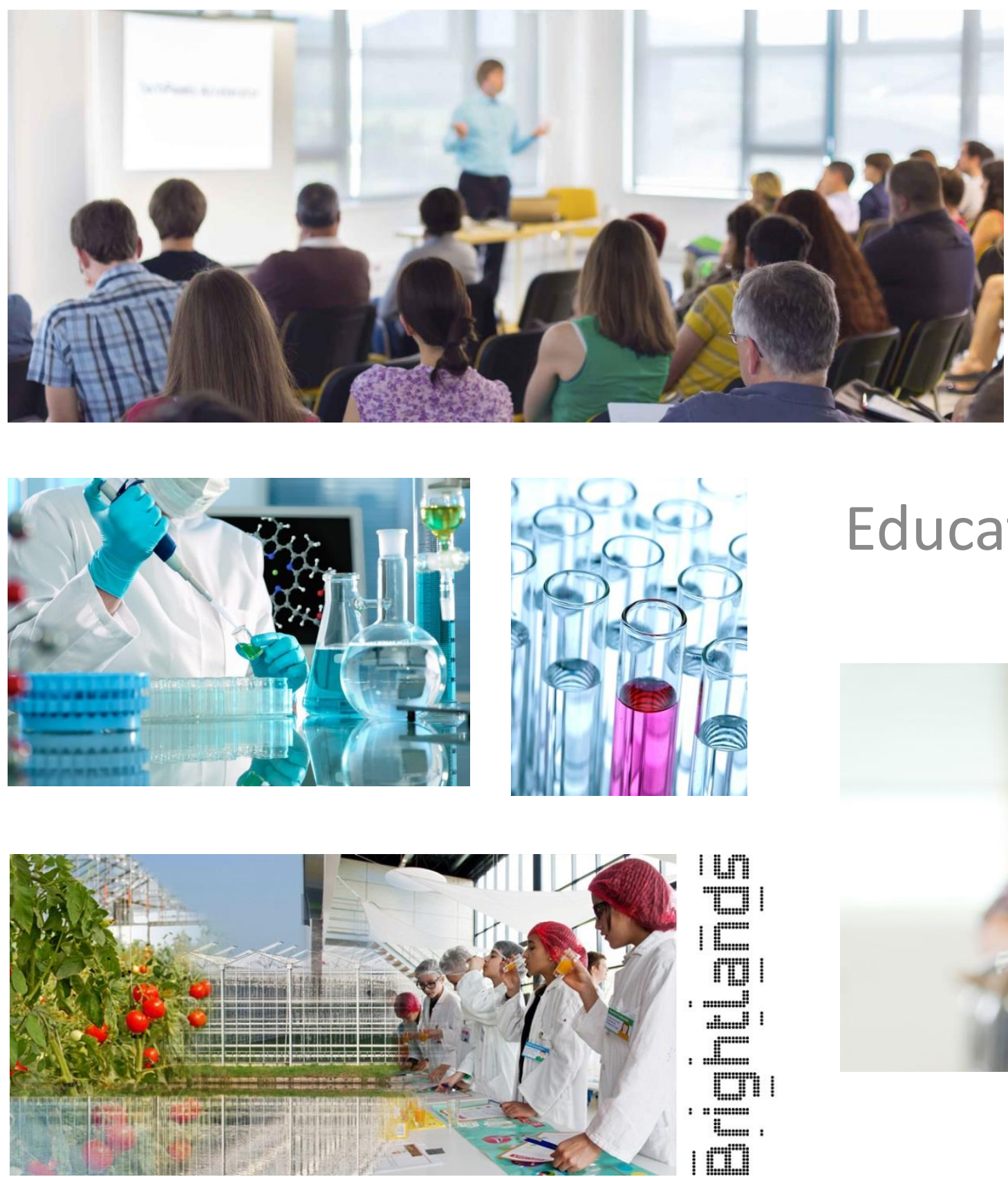

Education
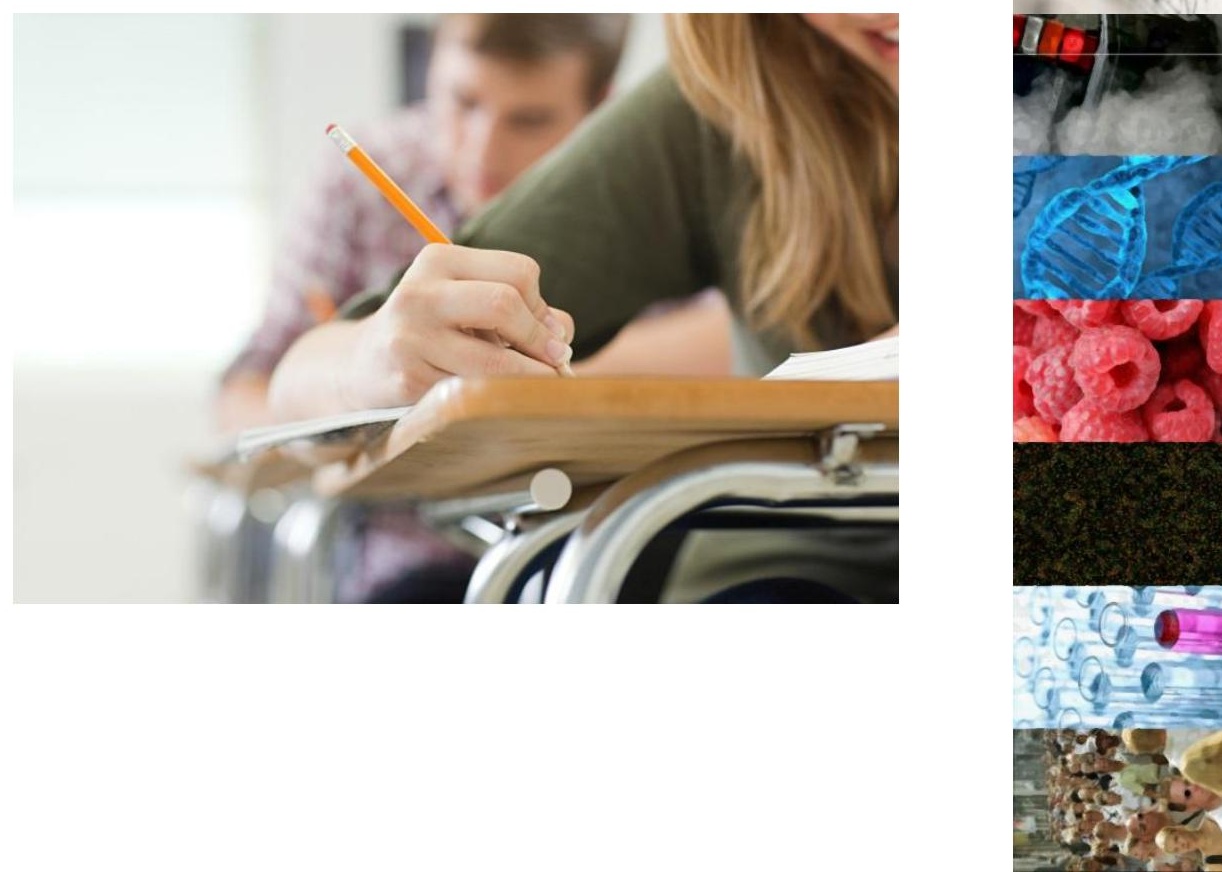


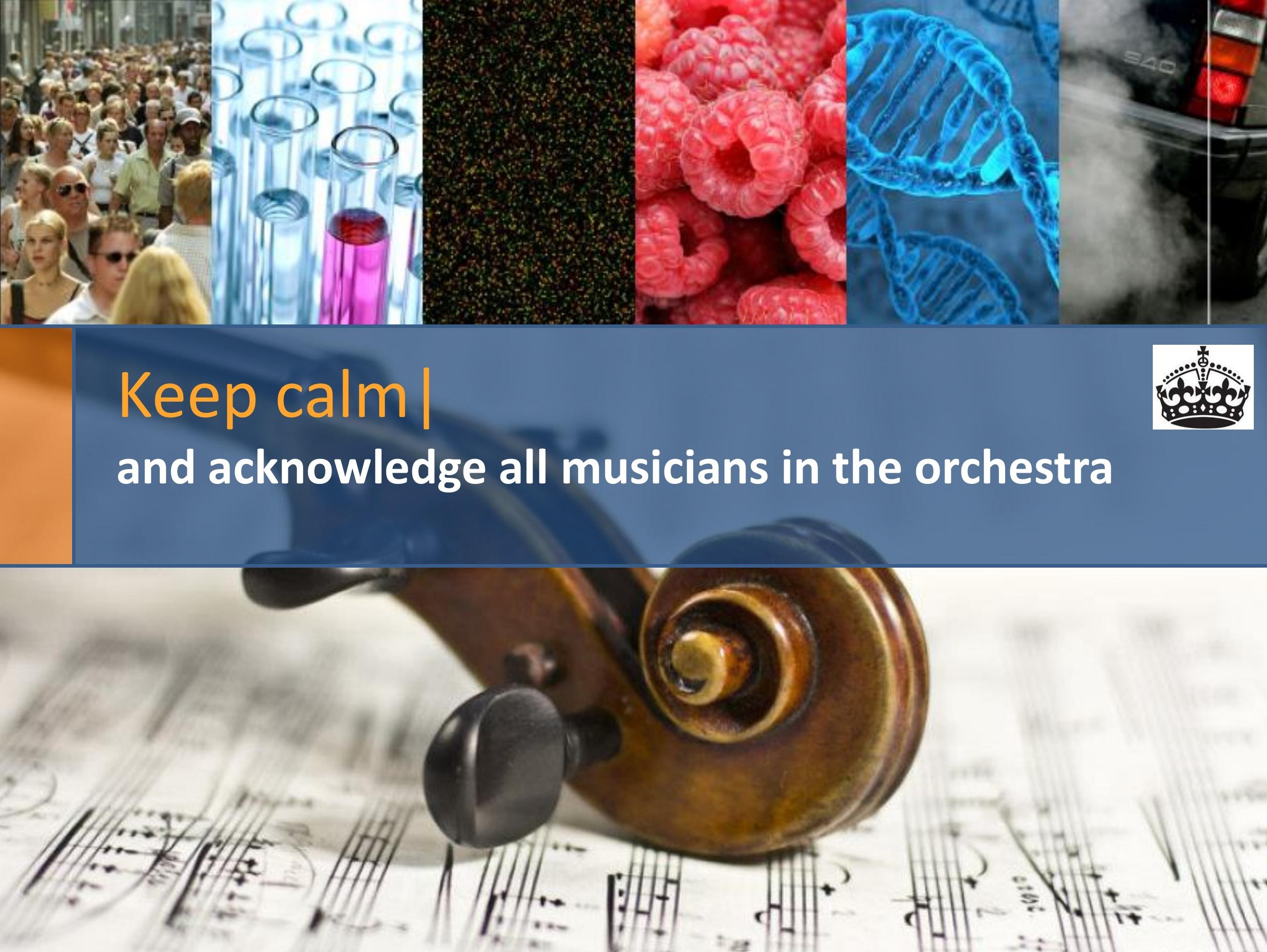

